NBER WORKING PAPER SERIES

\author{
WHY ARE SAVING RATES SO \\ DIFFERENT ACROSS COUNTRIES?: \\ AN INTERNATIONAL COMPARATIVE \\ ANALYSIS
}

Sebastian Edwards

Working Paper No. 5097
NATIONAL BUREAU OF ECONOMIC RESEARCH 1050 Massachusetts Avenue
Cambridge, MA 02138
April 1995

This is a revised version of a paper presented at the Seventh Interamerican Seminar on Economics (IASE), Mexico City, November 1994. A previous version was presented at the Conference on Growth Prospects in Latin America, held in Bogota, Colombia, June 27-28, 1994. I am indebted to Fernando Losada and Sebastian Valdes for very helpful assistance and comments. I am grateful to Eliana Cardoso and Agustin Carstens for their comments, and to Shahid Yusuf and Carmen Reinhart for discussions. I have benefitted from conversations with Martin Feldstein. This paper is part of NBER's research programs in International Finance and Macroeconomics and International Trade and Investment. Any opinions expressed are those of the author and not those of the National Bureau of Economic Research.

(C) 1995 by Sebastian Edwards. All rights reserved. Short sections of ext, not to exceed two paragraphs, may be quoted without explicit permission provided that full credit, including $($ ) notice, is given to the source. 


\title{
WHY ARE SAVING RATES SO \\ DIFFERENT ACROSS COUNTRIES?: \\ AN INTERNATIONAL COMPARATIVE \\ ANALYSIS
}

\begin{abstract}
This paper analyzes the determinants of savings in the world economy, and discusses why saving ratios have been so uneven across countries. A distinction is made between private and government savings, using panel data for 36 countries, from 1970 to 1992. In particular, it is assumed that government savings are not completely exogenous, and respond to both economic and political (strategic) determinants, along the lines of the recent literature on the political economy of macroeconomic policy.

Using instrumental variables estimation methods it is found that per capita growth is one of the most important determinants of both private and public savings. The results indicate that government-run social security systems affect private savings negatively. In addition, the results provide some support for the political economy perspective to government finances, which evidences a different underlying process determining public savings. Public savings tend to be lower in countries with higher political instability. Higher government savings crowd out private savings, but in a less than proportional fashion. Higher levels of foreign savings - i.e. reductions in the current account balance - are associated with lower domestic (both private and public) saving rates, although the degree of offset is also less than proportional. The degree of financial development turns out to be another important determinant of private savings. The results are mixed regarding the role of borrowing constraints - a topic deserving additional research attention.
\end{abstract}

Sebastian Edwards

The World Bank

1818 H Street, NW

Washington, DC 20433

and NBER 


\section{Introduction}

During the last few years there has been a renewed interest, in both academic and policy circles, on issues related to economic growth. New models and empirical studies have analyzed different aspects of this problem, including the conditions under which growth can be sustained through time. From a policy perspective this interest has been particularly high in Latin America where as a consequence of the debt crisis of the 1980s growth came to a halt for almost a decade. By 1992, and after an impressive process of market-oriented reforms, the nations of Latin America had recovered and were once again growing. The sense among analysts and policy makers, however, has been that the average real rate of growth for 1992-94 -approximately 3.0 percent -- was modest, and that in order to compensate for the stagnation of the so-called "lost decade" the rates of economic expansion should accelerate significantly. ${ }^{1}$ In discussing these issues a number of authors have pointed out that low saving rates are one of the most serious constraints faced by the Latin American countries. According to the World Bank (1993a) the median ratio of gross domestic savings to GDP was only 20 percent in Latin America in 1991, more than 15 points below that of the East Asian countries. Moreover, the Mexican peso crisis of December 1994 has highlighted the fact that low (and declining) saving rates have contributed to generating unsustainable current account deficits in many countries undertaking major structural reforms.

Traditional analyses on savings and growth have concentrated on two important issues: (a) the effect of higher savings on long run growth; and (b) the impact of an increase in domestic savings on investment. Neoclassical models inspired by the work of Solow (1956) suggest that an increase in saving ratios generates higher growth only in the short run, during the transition between steady-states. According to this view the long run equilibrium rate of growth will depend exclusively on structural demographic variables. Recent models based on theories of endogenous growth developed by Romer (1986) and Lucas (1988), however, predict that higher savings --

1. See, for example, World Bank (1993a) and CEPAL (1994). 
and the related increase in capital accumulation -- can result in a permanent increase in growth rates. ${ }^{2}$ This is because in the presence of externalities the marginal return to capital will be bounded from below and, under certain conditions, will exceed the rate of time preference. In this case the private sector will face a permanent incentive to add to the stock of capital, and growth will be sustained in the long run.

In an open economy, however, it is not necessarily the case that increases in domestic savings will be translated into higher domestic investment. In principle, if capital is internationally mobile, changes in domestic savings and investment can be completely independent. Savings generated in country A can (fully or partially) be invested in country B. If domestic savings and investment are uncorrelated, increases in the former will not be translated into a higher capital stock, and thus will not result in accelerated growth. If, on the other hand, the degree of international capital mobility is limited, higher domestic savings will generate higher domestic investment and growth. The extent to which domestic savings and investment are correlated is ultimately an empirical matter, as argued by Feldstein and Horioka (1980). There is by now abundant empirical evidence suggesting that domestic savings are highly correlated to aggregate investment. This indicates that, on average and over long periods of time, changes in capital accumulation respond mostly to changes in domestic savings. See Frankel (1985), Feldstein and Bacchetta (1991) and Montiel (1994). Empirical work by Barro (1991), De Long and Summers (1991), Edwards (1992) and others, has recently provided support to the notion that capital accumulation -- and thus savings -- are central for understanding growth differentials across countries. Moreover, in an important recent paper Young (1994) has argued that capital accumulation, and not technological progress, explains the splendid growth performance of the East Asian "tigers" -- Korea, Hong Kong, Singapore and Taiwan. The empirical evidence, however, is less clear when it comes to explaining savings

2. See, for example, the family of Ak models pioneered by Rebelo (1991). There is now an abundant literature on endogenous growth. See, for example, Grossman and Helpman (1991) and Sala-i-Martin (1992). See Gersovitz (1988), Deaton $(1990,1995)$ and Schmidt-Hebbel et al. (1994) for detailed surveys on the links between savings, growth and development. 
behavior across countries or along time. Existing work has been affected by the lack of detailed reliable data, and has either been controversial, as in the case of the interest responsiveness of private savings, or has offered limited help to policy makers that ask how saving rates can increase -- see Schmidt-Hebbel et al (1994) for a comprehensive survey.

The purpose of this paper is to investigate the process of determination of saving rates -- both private and public -- in the world economy. Additionally, this study discusses why saving ratios in Latin America have traditionally been so low, particularly in comparison to some of the most successful countries in the world. The analysis is based on international comparisons; data from 36 countries -- both OECD members and less developed nations -- are used to estimate a number of panel and cross country regressions. An important feature of the paper is that, in contrast with previous work, a distinction is made between private and government savings. ${ }^{3}$ In particular, I assume that government savings are not completely exogenous, and that they respond to both economic and political determinants. More specifically, I draw on the recent literature on the political economy of macroeconomic policy, and I argue that governments act strategically when deciding how much to save. In the empirical analysis presented in this paper I have also made an effort to incorporate the role of a large number of variables -- including policy, demographic, structural and political factors -- as possible determinants of saving ratios. The results obtained provide some useful insights on why saving rates are so different across countries, and will hopefully help determine an agenda for future detailed country specific research in the area.

The rest of the paper is organized as follows: Section II analyzes the recent behavior of savings in a selected number of Latin American and East Asian countries. In Section III I deal with conceptual and theoretical aspects of savings behavior. I

3. For example, in what is possibly the most comprehensive recent cross-country study of savings determination, Carroll and Weil (1993) use aggregate savings, without making a distinction between private and government savings. The lack of appropriate data has traditionally affected efforts to study in detail the behavior of savings in a broad comparative setting. Although advanced countries, and selected middle income countries, have distinguished between the two types of savings, these data have not been available for the poorer nations. 
present a basic model of private savings determination, I disucss a way endogenizing government savings, and I discuss some of the most important policy controversies that have affected savings analyses in the past. In section IV I report the results obtained from the estimation of a number of panel and cross country regressions on private and public savings. The paper ends in Section $\mathrm{V}$ with a brief discussion of policy implications and directions for future research.

\section{Recent Behavior of Saving Rates: A Comparative Perspective}

Broad comparative analyses of savings behavior have traditionally been plagued by data problems. ${ }^{4}$ Savings are usually estimated in a questionable way -- mostly as residuals --, and until very recently comparable data on private savings were restricted to a handful of advanced countries. Moreover, as of this point in time large international data sets on net savings are not available. In this paper I use a new data set assembled by the International Monetary Fund that distinguishes between private and government national savings ratios and permits undertaking empirical work on their determinants.

Table 1 contains the averages and distributions of private, government and aggregate national savings for a group of Latin American, Asian, African and industrialized countries for the 1970-82 and 1983-92 periods -- see the appendix for a list of the countries included in this sample. Figures 1 through 11 display, for all years for which there is information, the evolution of private, government and aggregate gross national savings for a group of eleven Latin American countries. Figures 12 through 16, on the other hand, present comparable data for five East Asian nations.

A number of interesting facts emerge from this table and figures. First, during the most recent period (1983-92) Latin America's private savings ratios have been the lowest in the world. Second, these data confirm the notion that in the post-debt crisis period private savings rates have tended to decline in Latin America. Third, and

4. See Gersovitz (1988) for a discussion on data problems in aggregate savings studies. 
apres 1

Sevings: Argentina

Oresomicopo of con

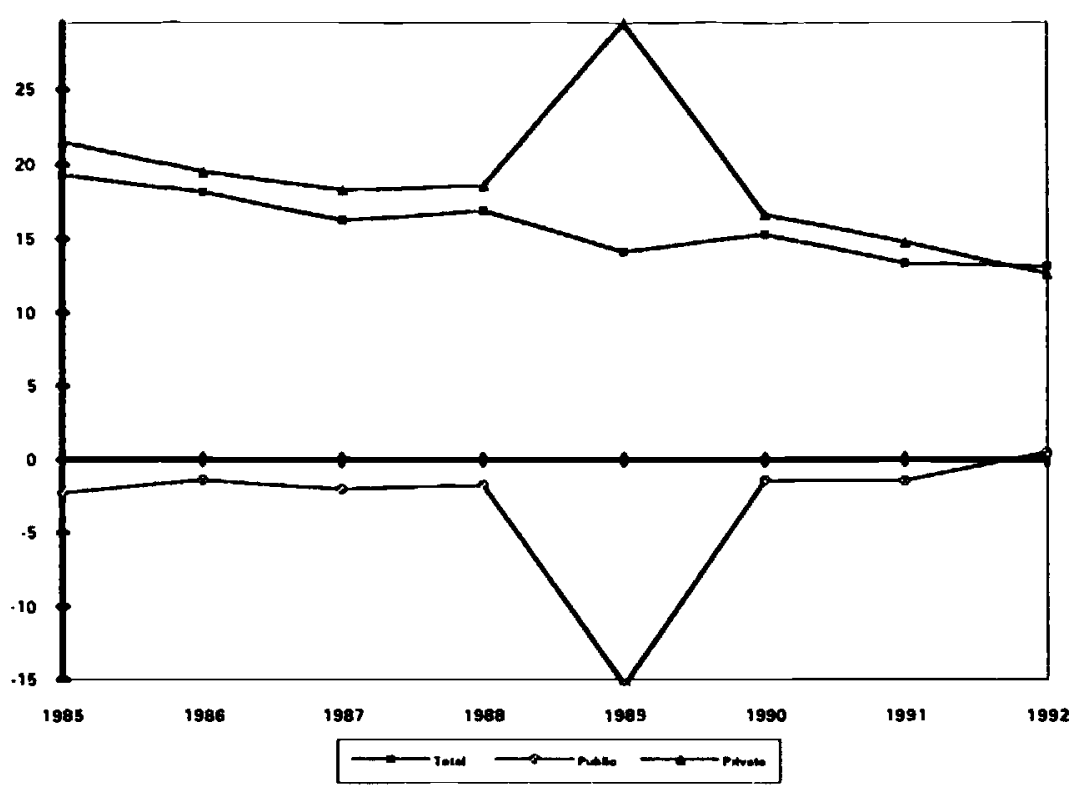

Fone 3

Sevings: Brezll

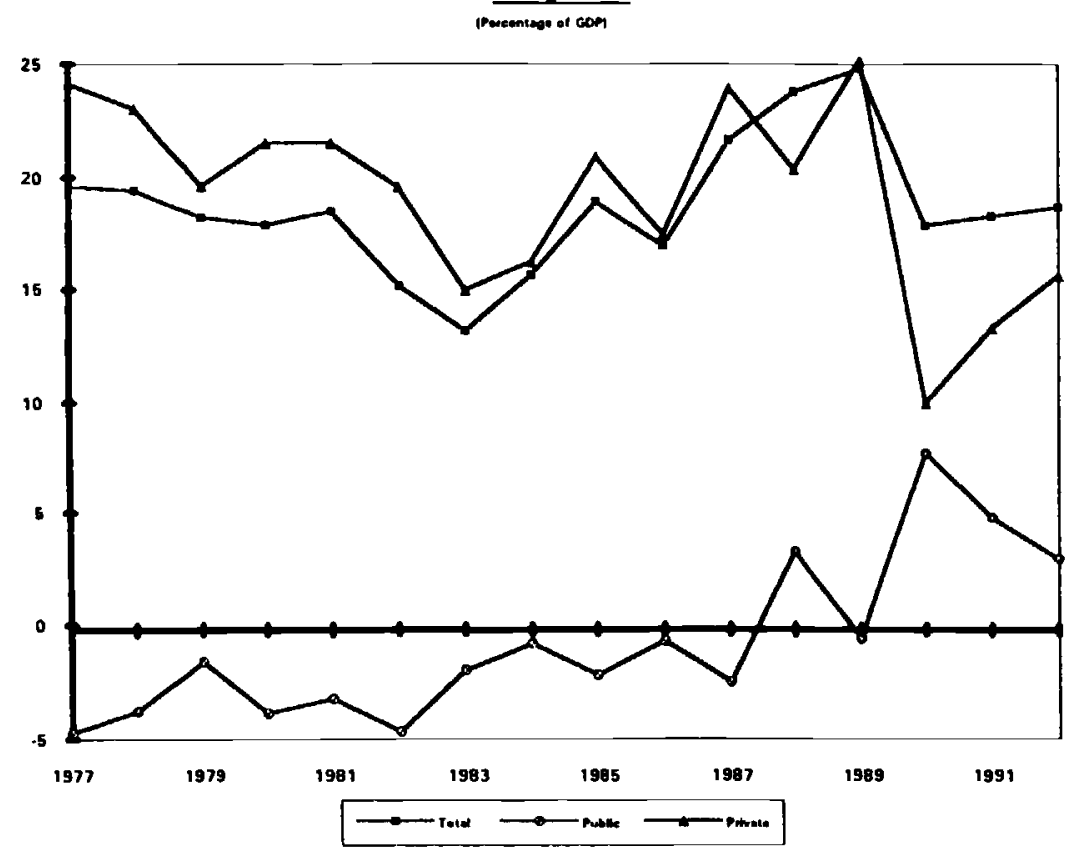

Fioure 2

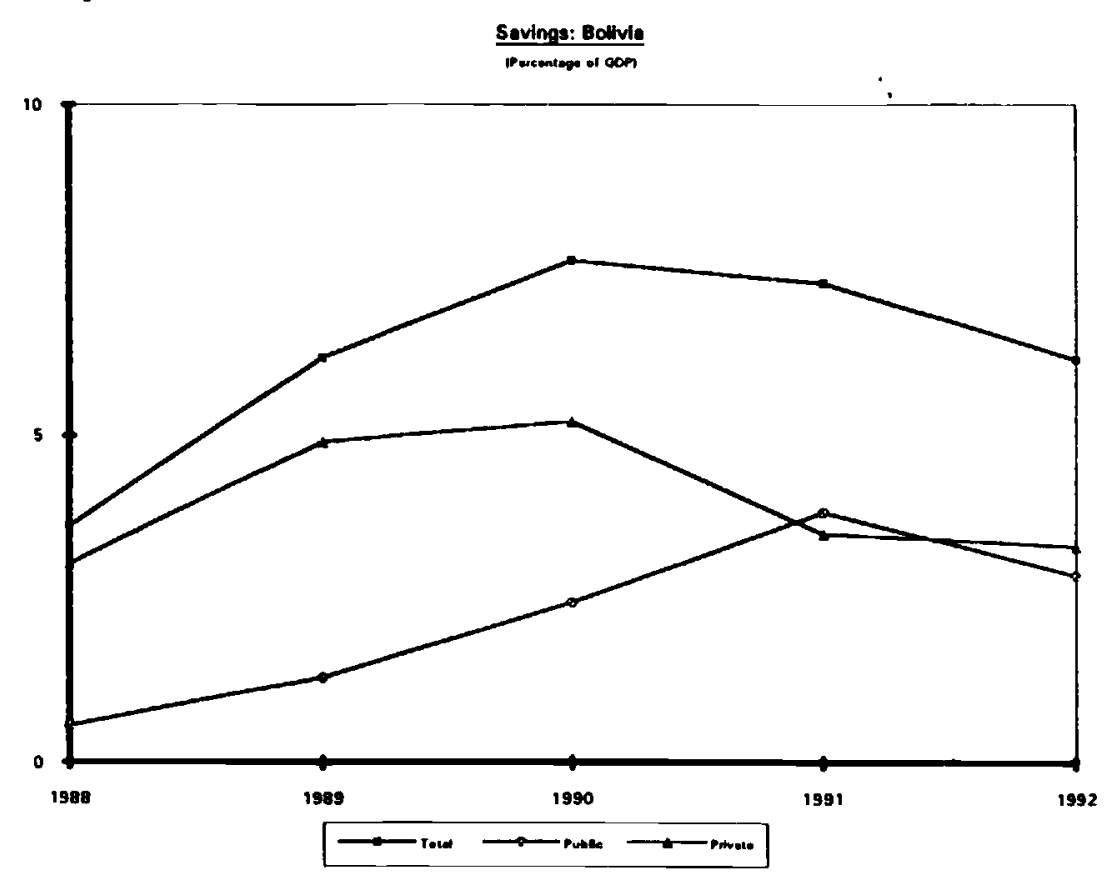

Fowe a

$\therefore$

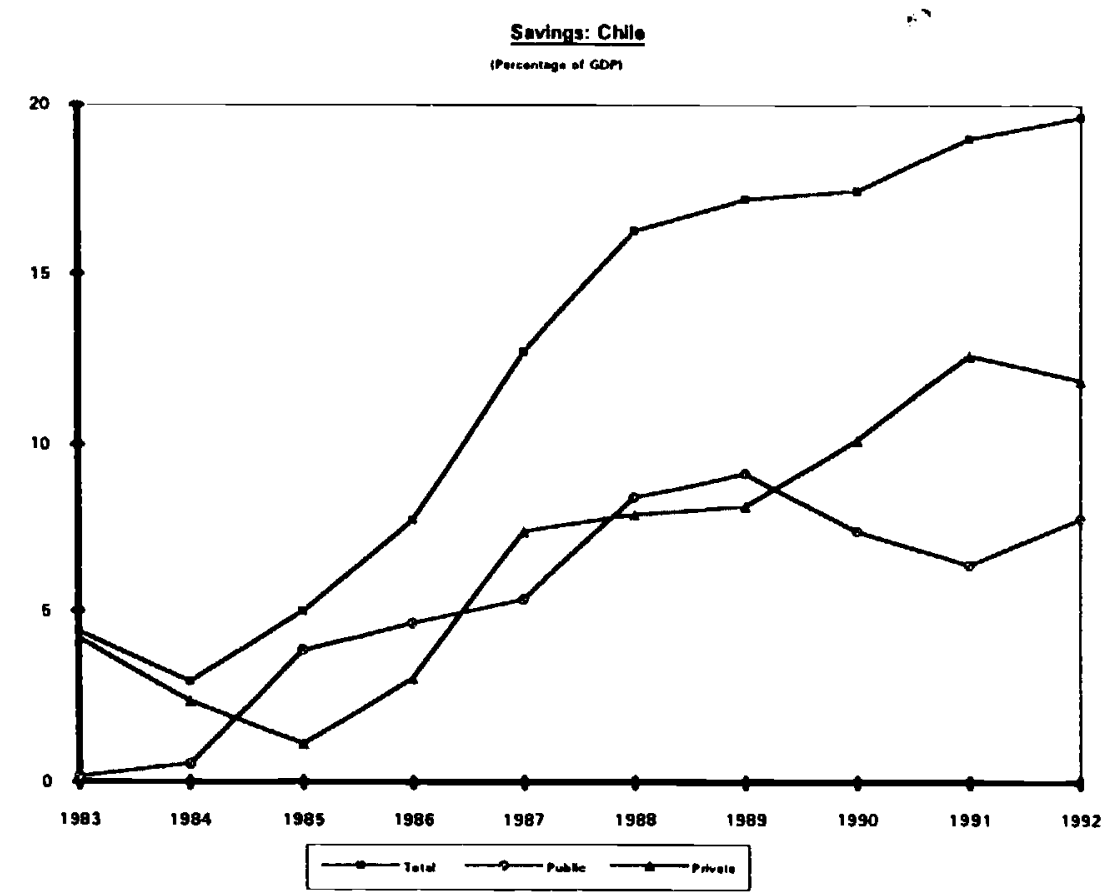

in

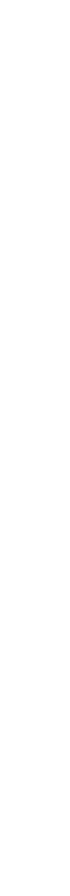


Fouro 5

Savings: Colomble

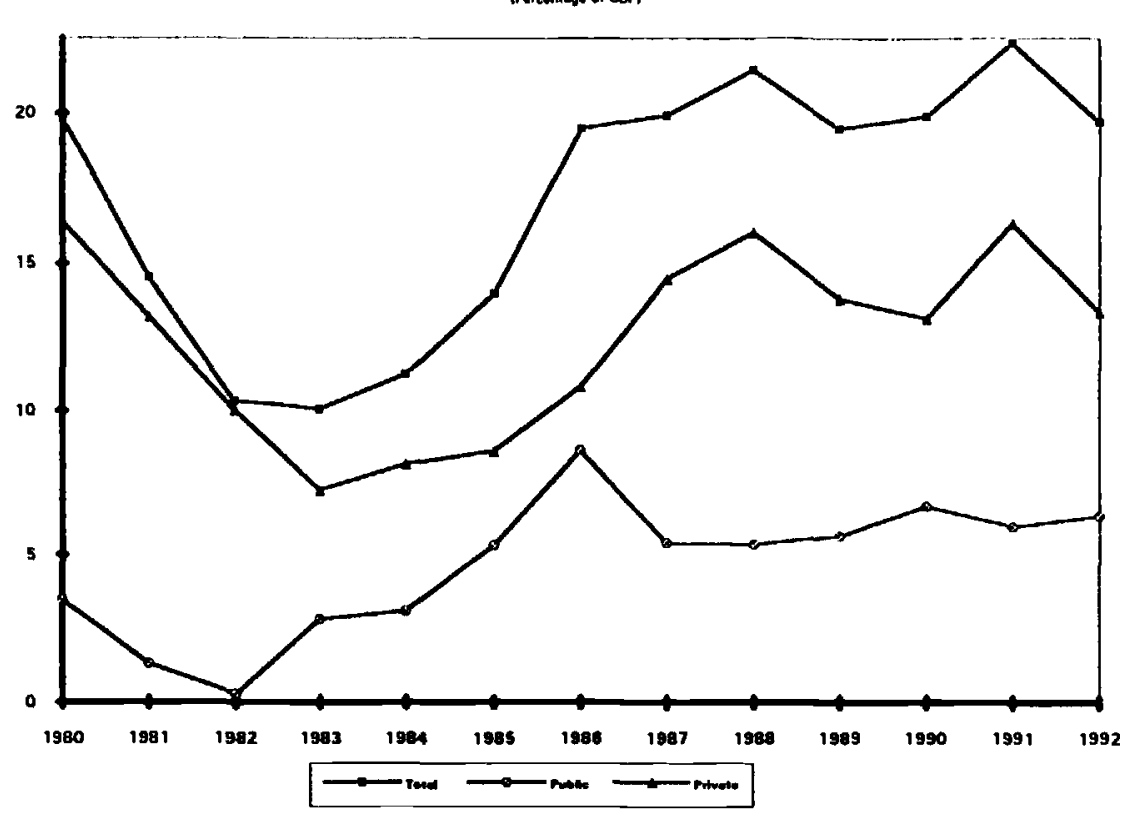

Fowro 1

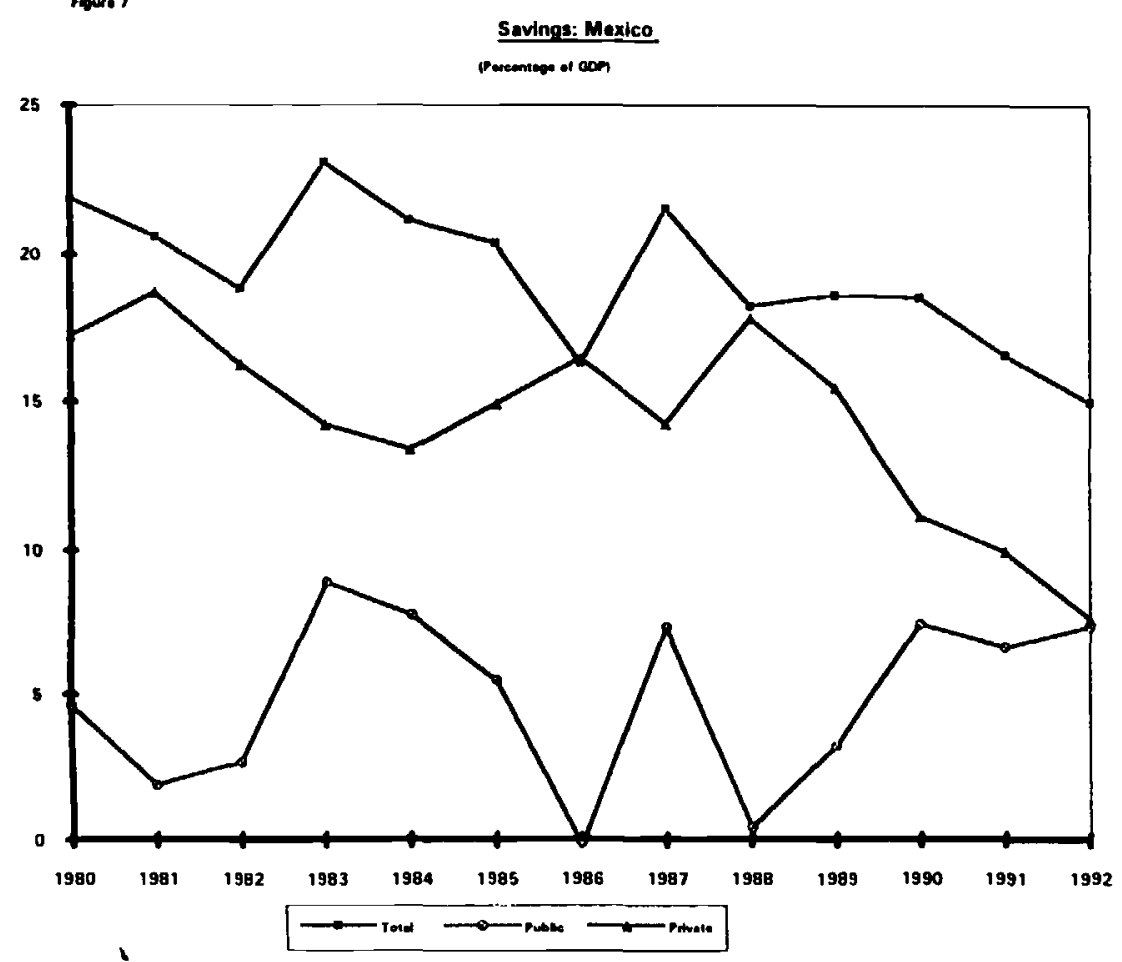

Foures

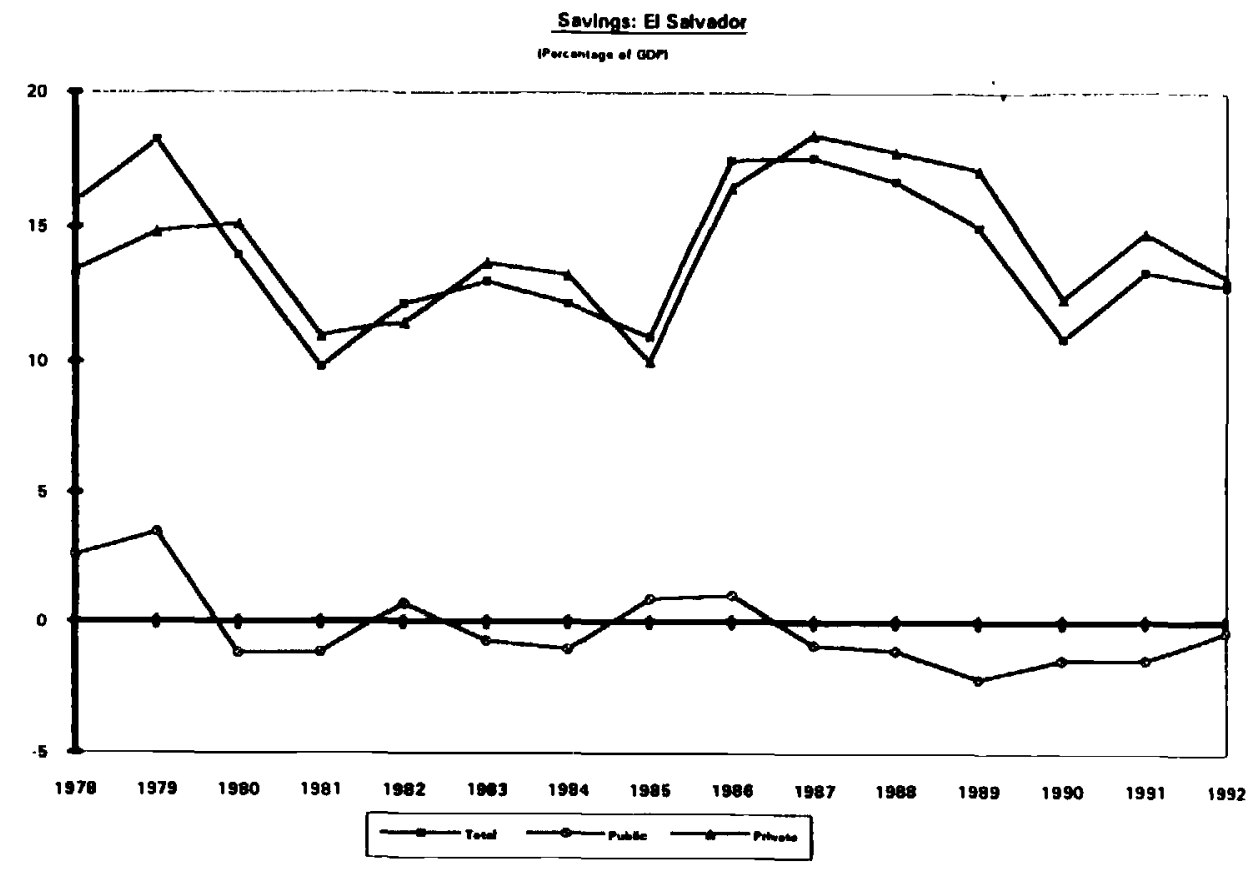

Fonre:

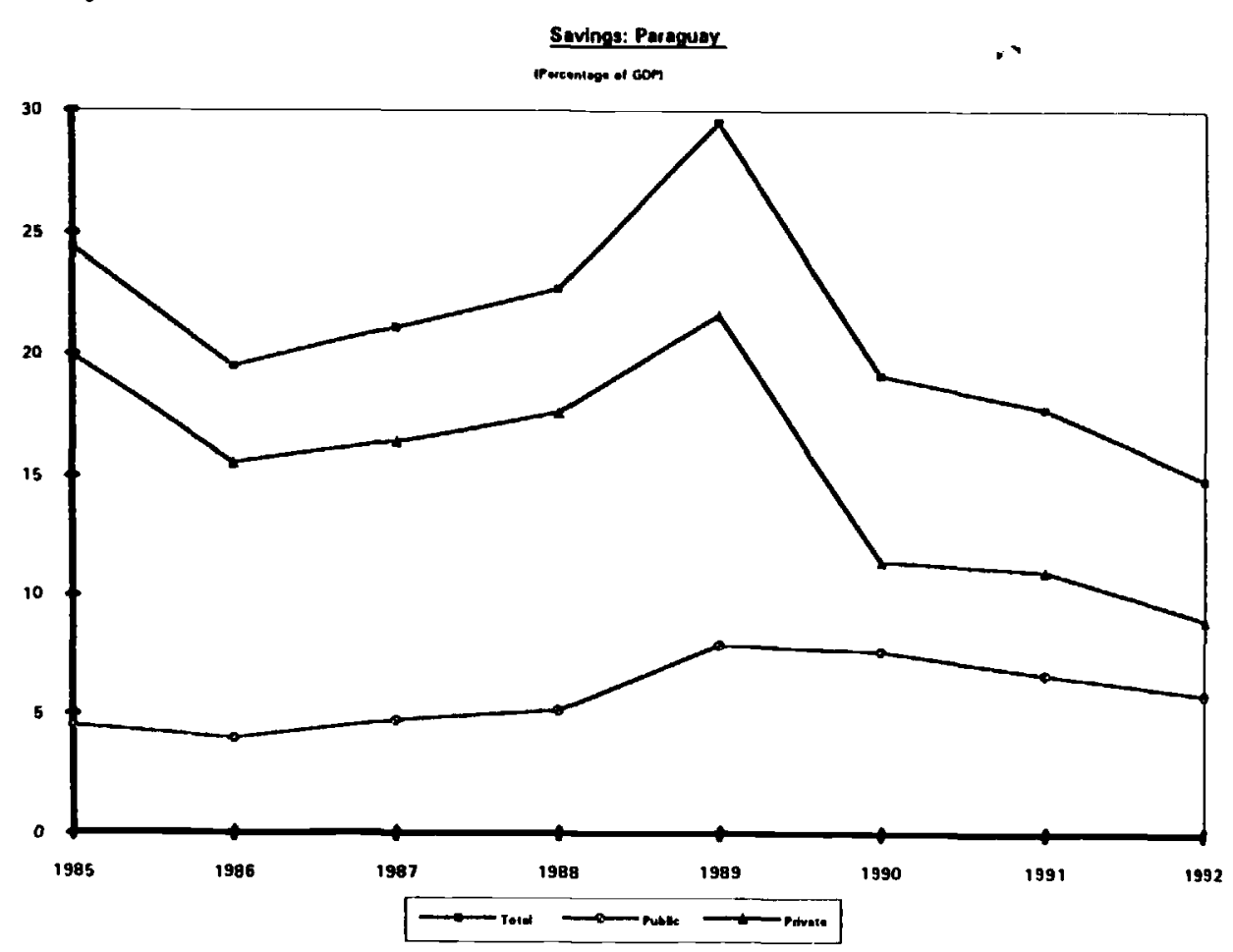

$a$ 
rowes 9

Sovings: Peru

resconicose of con

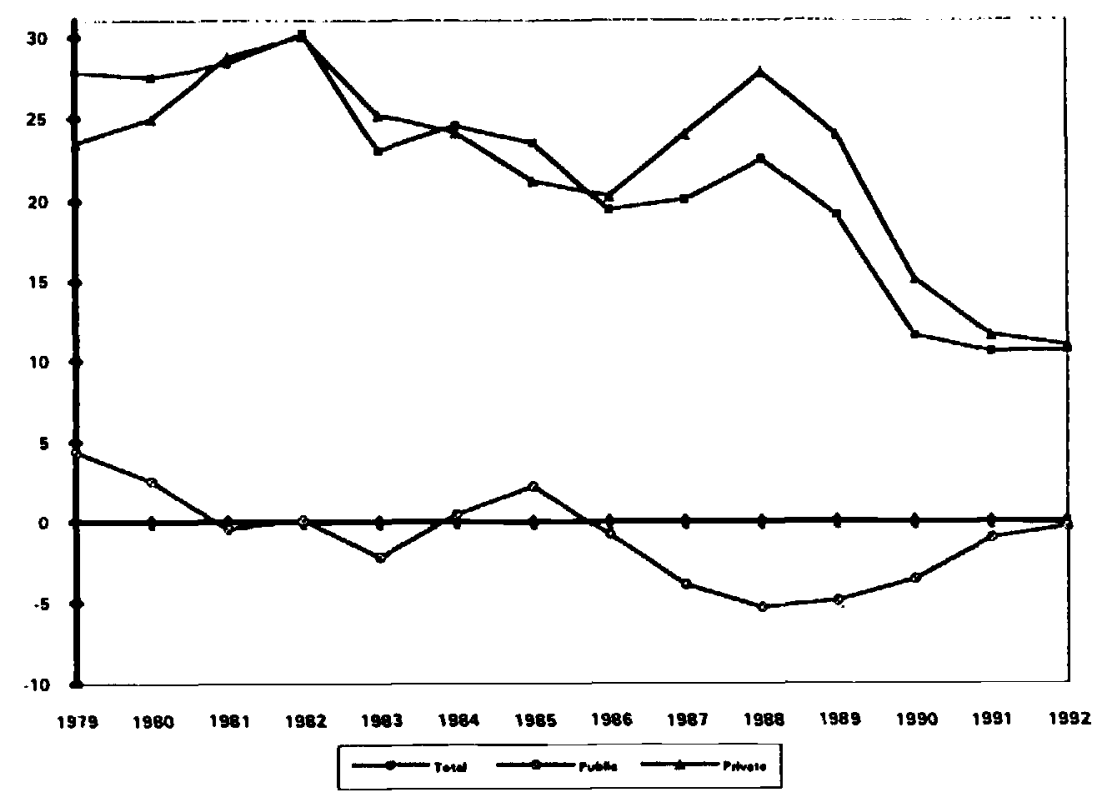

Foure 11

Savhrog: Venezuele

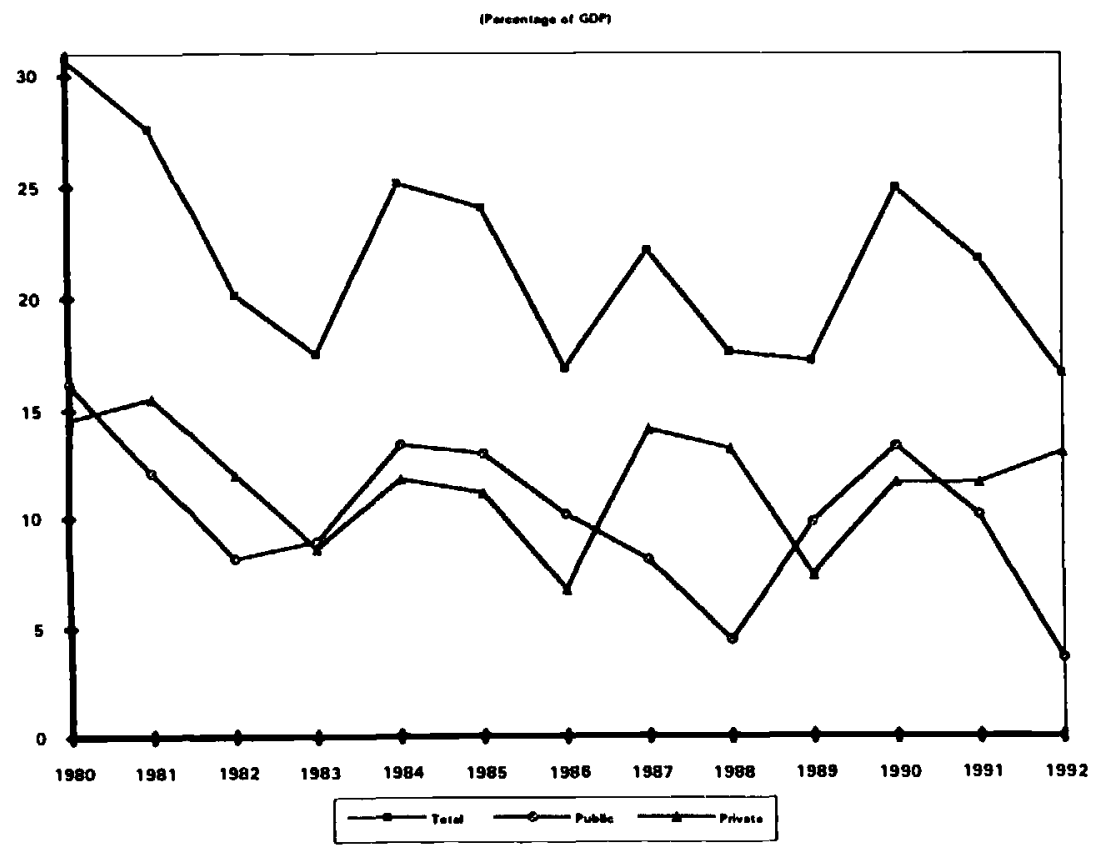

Frowe 10

Sevings: Trinidad and Tobage

ipercomisoos of con

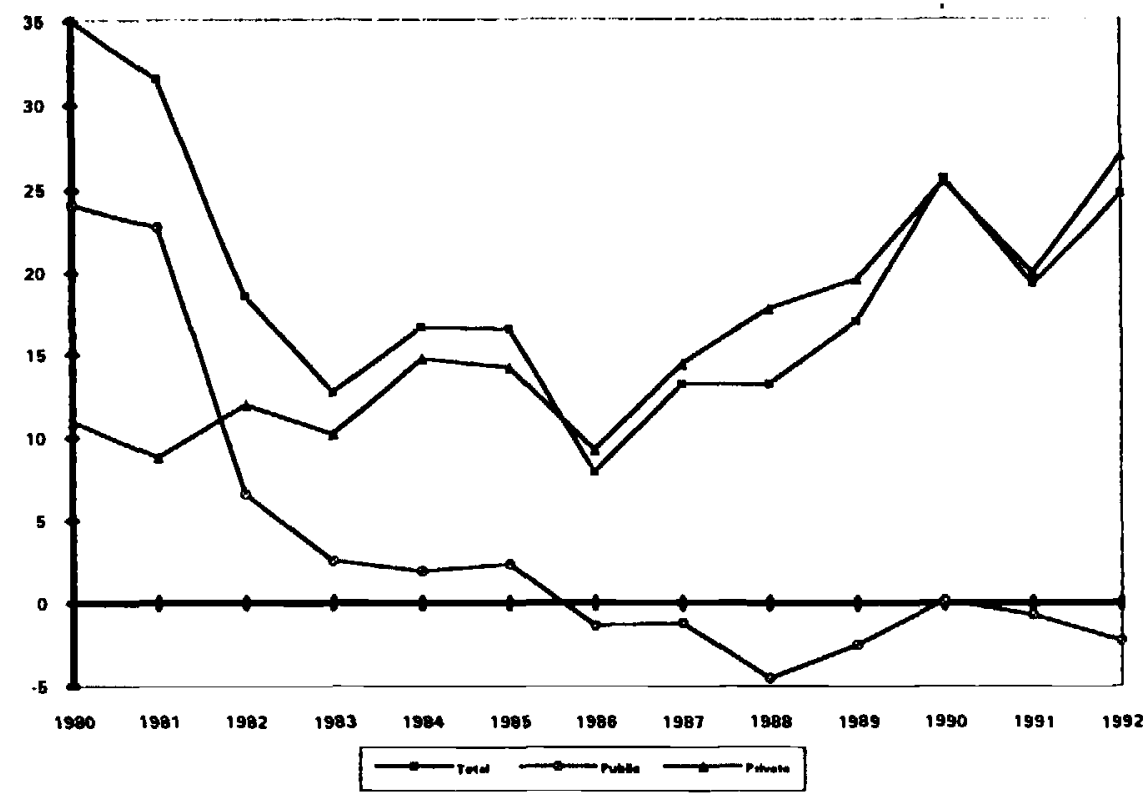

Moune 12

.

Inpen: Sminge

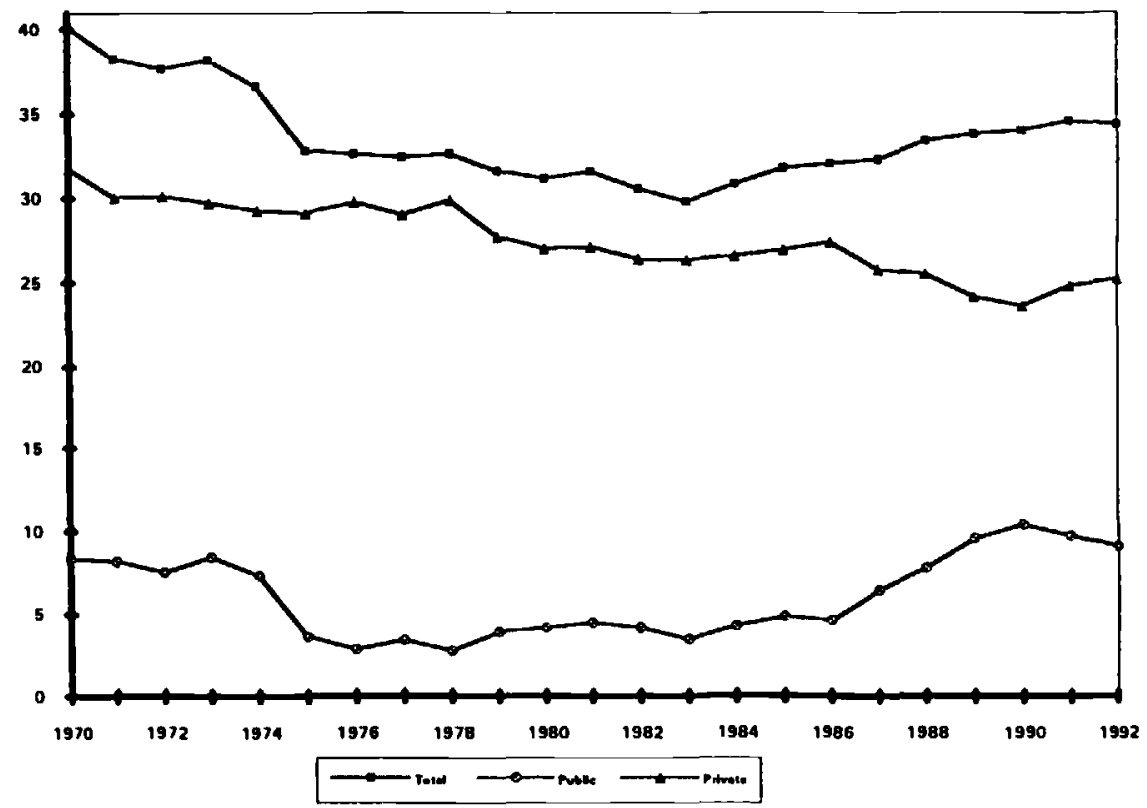



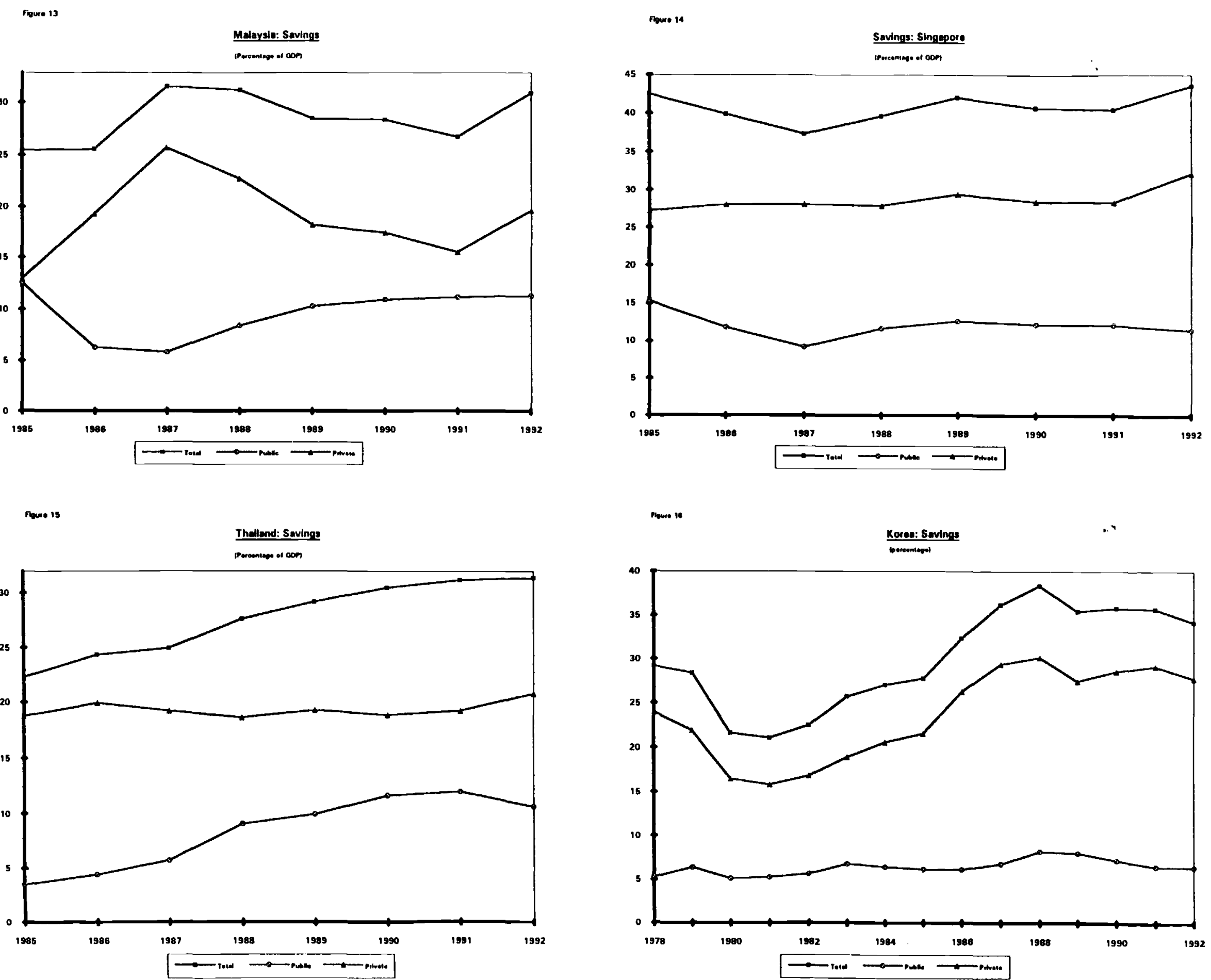
interestingly enough, the story regarding government savings is quite different: during the 1983-92 period the Latin American countries in this sample have exhibited comparatively high ratios. In fact, Latin America had the highest median and the second highest average government savings rates during 1983-92. This is particularly important because relatively high government saving rates is a rather recent phenomenon in Latin America, and one that is based on somewhat fragile bases. Moreover, recent data suggest that in some countries fiscal discipline may be slipping, generating a reduction in the government's contribution to aggregate savings. ${ }^{5}$ And finally, when private and government savings are consolidated in panel $\mathrm{C}$ of Table 1 , Latin America is once again at the bottom of the scale.

The data on the evolution of savings ratios for five high performing Asian countries provide important contrasts -- see figures 12 through 16 and Table 1 . These East Asian countries have not only had very high aggregate saving rates -- of the order of 30 to 40 percent --, but they have also been very stable. A second fundamental difference between the Latin and East Asian countries is that the contribution of government savings to total national savings is significantly higher in East Asia than in Latin America. While historically in Latin America government savings have barely contributed to national savings, in the East Asian countries in Figures 11-16 they represent between 25 and 40 percent of aggregate savings. Section IV of this paper contains a systematic attempt at explaining cross-country differentials in government savings rates, using some insights from recent models on the political economy of macroeconomic policy making.

\section{Saving Rates Determination: Theory and Policy Controversies}

There is by now an abundant theoretical literature on the determinants of private savings. Different authors have analyzed specific aspects of the problem, including how savings are affected by social security contributions (Feldstein 1980), how changes in interest rates affect intertemporal consumption (Gylfason 1993, Ogaki,

5. See, for example, The Financial Times, Friday October 28, 1994. 
Table 1

PRIVATE AND GOVERNMENT SAVING RATES 1970-92

A REGIONAL COMPARISON al

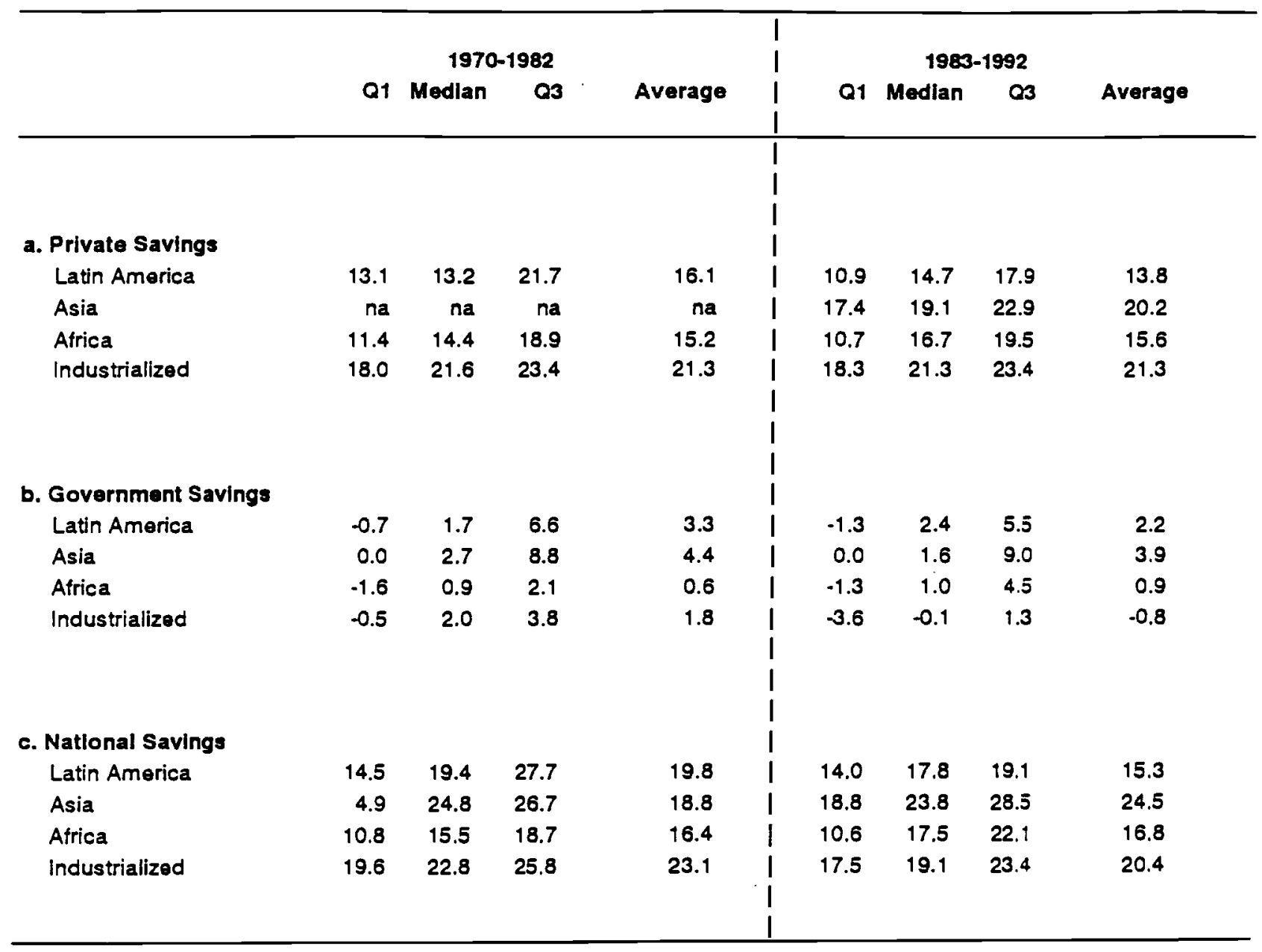

a) $Q 1$ is the first quartile, Q3 is the third quartile.

Source: IMF 
Ostry and Reinhart 1994), and how the existence of liquidity constraints impact on private savings decisions (Jappelli and Pagano 1994). The comprehensive surveys by Gersovitz (1988), Deaton (1989) and Schmidt-Hebbel et al (1994) suggest, however, that this literature has been somewhat fragmented; individual studies have tended to focus on one, or at most two, aspects of the problem. Because of its many policy angles and vast theoretical complexity, no single model has been able to deal with every dimension of the savings issue. This fragmentation has also been present -although to a lesser extent -- in the empirical literature on the subject: authors have typically concentrated on a few possible determinants of private savings in their attempts to understand their evolution. ${ }^{6}$

In contrast with the case of private savings, there has been almost no theoretical or empirical work trying to explain the behavior of government savings through time or across countries. ${ }^{7}$ Almost every analysis on the subject has either ignored the process through which government savings are determined, or has assumed that they are completely exogenous. What makes this particularly surprising is that, as pointed out in the preceding section, government savings have historically provided a very substantial share of total national savings in rapidly growing economies.

The purpose of this section is twofold: first, I briefly deal with the analytics of private sector savings behavior. This discussion focuses on some important policy controversies, and provides a conceptual base for the empirical analysis of Section IV. Second, I develop a framework based on political economy considerations for analyzing the process of government savings behavior. The main implications of this approach are used in the empirical analysis of cross country government savings presented in section IV.

6. See Gersovitz (1988) for a broad survey on savings and development. Aghevli et al. (1990) provide a very complete discussion of recent trends and prospects. Hayashi (1986) provides a fascinating analysis of Japanese savings, and deals with a slightly different question to the one we are addressing -he asks why is Japan's saving rate so high?

7. Summers (1988) provides a (partial) exception. See also the discussion in Feldstein and Bacchetta (1991). 


\section{III.1 The Analytics of Private Savings Behavior}

Whether and how much to save are fundamentally intertemporal decisions.

Households have to decide how much of their current income to consume in the present and how much to put aside for future consumption. ${ }^{8}$ This fundamental insight has been captured by a number of models that have focused on intertemporal optimization, including the life cycle theories originally developed by Franco Modigliani. ${ }^{9}$ Possibly the easiest way to formulate this problem for an (infinitely lived) individual is as follows:

$$
\max \int_{0}^{\infty} E\left\{U\left(c_{t}, g\right) e^{-\rho t} d t\right\} .
$$

subject to:

$$
\begin{aligned}
& \int_{0}^{\infty} c_{\mathrm{t}} \mathrm{e}^{-\mathrm{rt} d t} \leq \mathrm{W}, \\
& \mathrm{W}=\int_{0}^{\infty} \mathrm{y}_{\mathrm{t}}\left(1-\tau_{\mathrm{t}}\right) \mathrm{e}^{-\mathrm{t} t} \mathrm{dt}, \\
& \mathrm{S}_{\mathrm{t}}=\left[\mathrm{y}_{\mathrm{t}}\left(1-\tau_{\mathrm{t}}\right)-\mathrm{p}_{\mathrm{t}} \mathrm{c}_{\mathrm{t}}\right] \\
& -\mathrm{k} \leq \mathrm{S}_{\mathrm{t}} \leq \mathrm{y}_{\mathrm{t}}\left(1-\tau_{\mathrm{t}}\right) .
\end{aligned}
$$

$E$ is the expectations operator; $U()$ is the instantaneous utility function, which is assumed to be concave; $\rho$ is the rate of time preference, and $r$ is the interest rate. $c_{t}$ is private consumption in period $\mathrm{t}$, and $\mathrm{g}_{\mathrm{t}}$ is consumption of public goods during that period; at this point their supply is assumed to be exogenous. W is total wealth, $y_{t}\left(1-\tau_{)}\right)$is net income, $\tau_{t}$ is the tax rate in period $t, S_{t}$ is savings and is defined as

8. Most empirical studies have associated private savings to household savings. This is not strictly correct, since in a number of countries corporate savings are an important component of the aggregate. In this paper I follow most recent authors, and I do not deal with the theory of corporate savings. See, however, Gersovitz (1988) for a discussion. The empirical analysis of section IV, however, include both household and corporate savings.

9. See, for instance, Modigliani and Brumberg (1954). 
$\left[y_{t}\left(1-\tau_{l}\right)-p_{t} c_{l}\right] ;$ if in a given period $S$ is negative, the individual in question is borrowing from the financial system. The third restriction, $-k \leq S_{t} \leq y_{t}(1-\tau)$, establishes that in any period savings has to be less than net income, and borrowing cannot exceed $\mathrm{k}$. This equation establishes a "borrowing constraint" which, depending on the circumstances, may or may not be binding. In general, it is expected that this borrowing constraint will be more restrictive the less developed the financial system is. A particular form for the borrowing constraint is that at any point in time $t$, real wealth cannot be negative -- $\mathrm{W}_{\mathrm{t}}>0 .{ }^{10}$

The first order conditions from this problem are well known for the case where the borrowing constraint is not binding: the ratio between expected marginal utilities in any two periods has to be equal to the expected discount rate. An important implication of this result is that individuals will use borrowing and savings to smooth consumption through time. More specifically, if the marginal utility is convex there will be a precautionary motive for savings. Since situations of low consumption are particularly painful, households will tend to save during "plentiful" years to provide for hard times. ${ }^{1}$ This means that savings will tend to be higher in those economies where income is more volatile. From an empirical point of view this suggests that, with other things given, saving rates will be higher in countries where income is more variable. Generally speaking, this will be the case in countries that depend heavily on the agriculture sector.

If the utility function in (1) is quadratic and the rate of time preference is equal to the interest rate, consumption will be equal to the annuity of wealth as predicted by the permanent income hypothesis, and there will be no precautionary savings -- see Deaton (1989). A number of authors have argued, however, that the observed behavior of consumption and economic growth contradict the permanent income

10. On borrowing constraints see, for example, Deaton (1989) and Zeldes (1989).

11. For a detailed discussion on precautionary savings when the marginal utility is convex see, for example, Caballero (1990). 
hypothesis -- see, for example, Carroll and Summers (1991) and Carroll and Weil (1993). ${ }^{12}$

In spite of its simplicity, the model sketched above is able to capture some of the most important controversies that have dominated the savings policy debate during the last few years. In the rest of this subsection I discuss some of the dominant policy issues in this literature.

(a) Real interest rates and private savings. The effect of increases in (real) interest rates on savings has possibly been the most broadly discussed topic in this field. From a purely analytical perspective the answer is straightforward: it is easy to see from equations (1) through (5) that changes in $r$ will have an ambiguous effect on private savings. Whether they respond positively or negatively will depend on the relative strengths of the substitution and wealth effects -- see Gylfason (1993) for a recent discussion on the subject. The early financial liberalization literature in LDCs argued that one of the most important objectives of these reforms was to generate, among other things, a significant increase in domestic savings. In the original models of financial repression of McKinnon (1973) and Shaw (1973), allowing (real) interest rates to rise to market levels altered the intertemporal rate of substitution, encouraging aggregate savings. ${ }^{13}$

Empirical studies for a large number of countries-both advanced and developed-have found, however, only a weak interest rate elasticity of aggregate domestic savings. Boskin (1978), found a very low elasticity for the United States. A number of studies for the case of the developing countries, including Giovannini (1983) have failed to find a significant effect of interest rate changes on private savings.

12. Carroll and Summers (1991) present evidence suggesting that two key implications of the permanent income hypothesis are not born by U.S. data. First, contrary to this hypothesis anticipated income growth and consumption are not uncorrelated; second, the (real) rate of interest is not a strong determinant of the rate of growth of consumption.

13. See Fry (1988) for surveys of these types of models. 
McKinnon (1991) has recently acknowledged that "aggregate savings, as measured in the GNP accounts, does not respond strongly to higher real interest rates" (p. 22). ${ }^{14}$

The evidence suggesting that savings have a low degree of responsiveness with respect to interest rates has prompted analysts and policy makers to consider alternative policy mechanisms to encourage savings. Some countries, such as Chile in the mid1980 s, relied on tax reforms aimed at discouraging consumption. ${ }^{15}$ More recently a number of authors have suggested that shifting the tax base from income to consumption will encourage thrift in the economy as a whole. From an analytical point of view these policies rely on the assumption that there is a high intertemporal substitution in consumption. As pointed out, until recently the existing evidence did not support this contention, shedding some doubts on the effectiveness of these taxbased mechanisms to increase aggregate savings. ${ }^{16}$ In an important recent paper, however, Ogaki, Ostry and Reinhart (1994) have argued that the degree of intertemporal substitutability of consumption is a function of the level of income per capita. Their empirical results, using a large macroeconomic data set, provide some support to this view.

The financial liberalization hypothesis should be interpreted broadly, going well beyond the effect of higher interest rates on savings. Data from the rapidly growing East Asian countries suggest that a number of institutional developments in those

14. In spite of the relative unresponsiveness of savings to higher interest rates, financial reforms still have important effects on growth through improvement in the quality of aggregate investment, and especially private investment. For example, in a series of studies Gelb (1989), Fry (1988) and McKinnon (1991) have found robust evidence supporting the proposition that a reduction in the degree of repression of the capital market will tend to increase the productivity of investment. This work also suggests that reducing financial instability, and especially inflation, will also have an important positive effect on the return to investment. Also, recent work by King and Levine (1993) provides support to the idea that more developed financial sectors have been associated with faster total factor productivity growth.

15. That provision was altered in the 1990 tax reform. See the discussion in Edwards (1993). See also Edwards and Cox-Edwards (1991).

16. Carroll and Summers (1991) have argued that the comparison of the evolution of Canadian and U.S. tax systems provides an ideal natural experiment for investigating the way in which tax regimes affect savings rates. They conclude that tax systems that encourage postponed consumption -- such as Canada's -- indeed result in higher savings. 
nations -- including efficient prudential supervision and the encouragement of postal savings -- have positively affected private savings. Unfortunately, it is extremely difficult to find time series and/or cross country data on these indicators to be used in empirical work. Defining appropriate proxies for the degree of financial development is, indeed, one of the challenges faced by empirical researchers.

(b) Time profile of income flows, demographics and economic growth. According to life cycle models individuals will have negative savings when they are young and have very low income, positive savings during their productive years, and once again negative savings when they are old and retired. Also, if individuals have positive bequest motives, they will tend to leave some wealth to their heirs. According to this view, then, aggregate private savings will be affected by the age distribution of the population. If there are a large number of inactive people relative to those in their productive years, aggregate savings will be relatively low. In their classical studies, Modigliani (1970) and Leff (1969) used cross-country data (mostly on advanced nations) to test this hypothesis. They found, as have numerous authors after them, that differences in demographics indeed play a key role in explaining differences in savings.

Modigliani (1970) also argued that in a life-cycle setting income growth will have an important positive effect on private savings. This is largely the result of aggregation across households. To the extent that the economy is growing, workers' savings will increase relative to retirees' dissavings and, thus, measured aggregate savings will increase. As Bosworth (1993) has pointed out, however, there will also be an effect moving in the opposite direction. In a growing economy workers will anticipate future income increases and, as a result, will tend to increase present consumption and reduce savings. Whether the positive or negative effect will dominate is ultimately an empirical matter. A problem with analyzing this issue empirically, however, is that there is a two-way causation. On one hand, growth will tend to affect savings through the mechanisms just described, and on the other, savings will tend to impact growth through their effect on capital accumulation. Some authors, however, have tried to deal with this endogeneity problem through a series of mechanisms, 
including the use of instrumental variables techniques and the computation of causality tests. In a recent paper, for example, Carroll and Weil (1993) have used detailed household-level data to deal with this issue and have concluded that there is evidence suggesting that growth indeed affects private savings positively. ${ }^{17}$

The positive influence of growth on savings has played a central role on recent analyses of successful development experiences in east Asia. According to the World Bank (1993b), for example, in these countries there has been a "virtuous circle" going from higher growth, to higher savings, to even higher growth.

(c) Borrowing constraints. The extent to which individuals can actually dissave when young will depend on their ability to borrow. If the borrowing constraint in equation (5) is binding, the marginal utility of present consumption will exceed the (discounted) expected utility of future consumption; households would like to increase present consumption but will be unable to do so (Zeldes 1989). In most models, once the borrowing constraint is made less stringent, present consumption will increase and, thus, national savings will tend to decline. ${ }^{18}$ What makes this result particularly interesting, is that it suggests that financial reform programs of the type long advocated by a number of economists such as McKinnon (1973) and Shaw (1973) could result in a reduction in savings, capital accumulation and, ultimately, in the rate of growth. In an important recent paper Jappelli and Pagano (1994) have used cross country data on required down payments for mortgages as a proxy for borrowing constraints. Their econometric results on data for advanced countries support the idea that relaxing these constraints will reduce savings and economic growth. In their analysis of household savings behavior for a group of developing countries, Schmidt-Hebbel et al (1992) used beginning-of-period money balances as an indicator for the stringency of the borrowing constraint, and found that its coefficient was negative.

17. Surprisingly, however, a number of empirical studies on savings continue to ignore the endogeneity of the rate of growth. See, for example, Schmidt-Hebbel et al (1992) and Doshi (1994).

18. Gersovitz (1988) makes the important, but often forgotten, point that even though savings will be higher with borrowing constraints, household's welfare will tend to be lower. 
(d) Taxes, government consumption, and social security. The model presented above suggests that fiscal policy -- changes in $\mathrm{g}$ and/or $\tau$-- will have an effect on consumption and saving decisions. What is interesting about this formulation is that both present and future taxes will tend to reduce savings. This means that, to the extent that the government is subject to an intertemporal budget constraint, it will not matter whether increases in government consumption are financed by higher taxes or by issuing government bonds. This is, of course, the Ricardo-Barro proposition that government bonds are not net wealth -- see Barro (1974).

Increases in government consumption will also affect private savings. If the public does not value government consumption, savings will decline; this will be the case independently of the way in which the expansion of government expenditure is financed. If, on the other hand, the public values public goods, the effect of an increase in their provision will depend on the degree of substitutability of $c$ and $g$ in the individual's utility function in equation (1). From an empirical and policy perspective it is important to determine whether increases in government savings will be offset fully by declines in private savings, or if the offset coefficient will be lower than one. Another important policy issue is whether changes in alternative taxes -value added tax, assets tax, income tax -- will have the same effect on private savings (see Kotlikoff 1984).

Corbo and Schmidt-Hebbel (1991) used a thirteen-country data set to analyze the macroeconomic consequences of higher public savings. In particular, they investigated the extent to which an increase in government savings would be reflected in a decline in private savings. They found that, although government savings crowd out private savings, the magnitude of this effect is far below the one-to-one relationship suggested by the simple Ricardian equivalence doctrine; overall their empirical analysis strongly indicates that an increase in public savings will be translated into higher aggregate savings. ${ }^{19}$ Corbo and Schmidt-Hebbel also found that, on average, increasing public savings via reduced expenditures is more effective than increasing taxation.

19. On Ricardian-Barro equivalence, see Barro (1974). 
Another important implication of the life cycle framework -- and one that can be easily incorporated into the formal model -- is that private savings will be affected by the extent and coverage of government-run social security programs. If individuals perceive that when they retire they will get high social security benefits, they will tend to reduce the amount saved during their active days (Feldstein, 1980). From a policy perspective this suggests that a social security reform that replaces a government funded system by a privately administered one, will tend to increase private savings. ${ }^{20}$

(e) Other potential determinants of private savings. Although the model sketched above captures the essentials of household savings decisions, it has some limitations. In particular, the model discussed here ignores consumers' heterogeneity, and thus the effects of income distribution on savings; it does not incorporate directly the role of human capital accumulation; it deals only partially with issues related to the effect of the degree of development of the capital market; it does not incorporate the possible effects of macroeconomic stability, including inflation; it does not have a direct role for political considerations, such as the effect of political turmoil, violence and instability on savings; it ignores open economy angles; and it ignores the role of firms' savings. Models with heterogeneous agents generally predict that households with higher income will tend to save a higher proportion of their income. At the aggregate-comparative level this has been interpreted as suggesting that countries with more unequal income distribution will tend to have a higher savings rate. From the instability perspective, it has been suggested that both macroeconomic as well as political instability will tend to have a negative effect on aggregate savings. Open economy models add two perspectives to the analysis: first, domestic interest rates will be linked to international interest rates; second, in open economies agents can use foreign borrowing to smooth consumption through time. This means that foreign savings will, generally, act as substitutes to domestic savings (see Obstfeld, 1995). In the empirical analysis reported below I include many of these variables as possible determinants of cross country differences in aggregate private savings.

20. Strictly speaking, what matters is the relation between contributions and expected social security benefits in the future. Whether aggregate savings increase will depend, however, on what happens to government savings once the social security reform is implemented. 


\section{III.2 Explaining Government Savings: A Political Economy Perspective}

Studies on savings have traditionally focused on aggregate national savings and/or on private savings, and have tended to ignore the process of determination of government savings. And yet, as discussed in section II, government savings can be a fundamental component of national savings, representing in some cases -- and especially in the successful East Asian nations -- between 30 and 40 percent of the aggregate. Most studies make the very simple -- and implausible -- assumption that government savings are exogenous, and are set by the economic authorities in a way that maximizes (the present value) of society's welfare.

In recent years a number of authors have relied on insights from public choice and game theory to study government behavior -- see Persson and Tabellini (1990) for a comprehensive discussion. Many of these models have assumed that political parties alternate in power, and that the group in office acts strategically, in an intertemporal sense, when making decisions that have economic consequences that span more than one period (Cukierman, Edwards and Tabellini, 1992). This type of approach can be extended fruitfully to address cross country differentials in government savings rates.

Assume that there are two political parties ( $\mathrm{L}$ and $\mathrm{R}$ ) that alternate in power according to some probability rule. Further, assume that $\mathrm{L}$ and $\mathrm{R}$ have different preferences: while $L$ prefers a vector of goods $h, R$ prefers vector $f$. The amount of these goods that society can produce and consume will depend, in part, on the level of government savings and investment. Savings, however, are only translated into higher investment, production and consumption with a lag. It is possible, thus, that while the party in power increases government savings, the projects come into fruition when its opponent will be in power -- for a formal description of the model see, for example, Edwards and Tabellini (1994).

In this setting the authorities' incentive to increase government savings -- and thus the ability to produce public goods -- will depend on two fundamental politicaleconomy variables: first, it will depend on the probability that the party in power will still be in office in the subsequent period. If this probability is low, the opposition party is likely to be in office once the projects mature, and will get the credit from the 
increased production of the public goods. Naturally, under these circumstances the incentives to increase savings will be low. The recent political-economy literature on inflation and stabilization has associated the probability of the incumbent to remain in office with the degree of political instability in the country in question. This analysis predicts, then, that the higher the degree of political instability, the lower government savings. The second determinant of government's incentives to save is the extent to which the political parties have different preferences. In the extreme case where their preferences are exactly the same, there will be a high incentive to government to save, even if the probability of remaining in office is low. The difference in parties' preferences has been referred in the political economy literature as the degree of political polarization. This analysis predicts that, with other things given, a greater degree of polarization will result in lower government savings. In regression analyses, however, it has been difficult to find empirical counterparts for political polarization. Some authors, such as Cukierman, Edwards and Tabellini (1992), for example, have argued that the frequency of politically motivated attacks and assassinations are appropriated proxies.

\section{Estimation}

In this section I present the results obtained from the estimation, on a 36 country data set -- eleven industrialized nations and twenty five from the developing world, of private and government savings equations. The estimation was performed on panel data for as many years as were available from 1970 to 1992 . Some equations were also estimated on cross country data based on averages for 1983-92. The results obtained from these equations were then used to address the questions of why saving rates are so different across countries and, more specifically, why are they so low in Latin America.

\section{IV.1 Private Savings}

Based on the discussion in section III, a number of equations of the following type were estimated for private saving rates: 
$s_{\mathrm{tk}}=a_{0} L_{\mathrm{tk}}+\mathrm{a}_{1} \mathrm{G}_{\mathrm{tk}}+\mathrm{a}_{3} \mathrm{~F}_{\mathrm{tk}}+\mathrm{a}_{4} \mathrm{M}_{\mathrm{tk}}+\mathrm{a}_{5} \mathrm{D}_{\mathrm{tk}}+\mathrm{a}_{6} \mathrm{E}_{\mathrm{tk}}+\mathrm{a}_{7} P_{\mathrm{tk}}+\mathrm{a}_{8} S_{\mathrm{tk}}+\mathrm{u}_{\mathrm{tk}}$,

where the subindex tk denotes country $\mathrm{k}$ in period $\mathrm{t} . \mathrm{s}_{\mathrm{tk}}$ is the private national savings rate for country $\mathrm{k}$ in period $\mathrm{t} ; \mathrm{L}$ is a vector of life-cycle variables, including the age dependency ratio, the rate of growth of per capita GDP, the ratio of old and young population. $\mathrm{G}$ is a vector of variables related to fiscal policy, and in principle it includes the government savings rate, government consumption, and the ratio of social security expenditures to total government expenditures (which are used as a proxy for expected social security benefits). $F$ is a vector of variables that capture the characteristics of the financial sector, including its degree of development. Of particular interest here are the degree of financial depth of the economy and the extent to which borrowing constraints are binding. Ideally, $\mathrm{F}$ would also include measures of the real interest rate and the borrowing-lending interest rate spread; however, these variables are only available for a small number of developing countries. $M$ refers to macroeconomic stability variables, including the rate of inflation; $E$ includes variables related to the external sector, such as the current account balance (or foreign savings); $P$ is a vector of variables that capture the characteristics of the political system; and $S$ captures all other variables not included above.

The estimation of private savings equations of the type of (6) presents several challenges. First, there are no data on all the relevant independent variables; second, a number of them are measured with error; and third, there are a series of instances of endogeneity, which sometimes raise questions of causality. ${ }^{21}$ In order to deal with these issues I have defined proxies for some of the variables of interest, and I have estimated the private savings equation using instrumental variables (IV) techniques. As it is usually the case with panel data regressions, it is rather difficult to find appropriate instruments. In this paper I have faced this problem by using lagged values of the

21. In particular, the rate of growth of GDP per capita, the (real) interest rate and the current account are likely to be endogenous. 
endogenous variables, as well as variables that are exogenous to savings but correlated to some of the endogenous variables, such as exports and population growth. ${ }^{22}$

Table 2 contains the results obtained from the estimation of private saving equations using instrumental variables on panel data for the 36 countries listed in the appendix. The dependent variable is the ratio of private national savings to GDP, and was obtained from the International Monetary Fund. The independent variables fall in the different categories described above, and were defined in the following way:

(a) Age dependency: population younger than 15 years old plus population over 65 years old, as a percentage of working-age population. This variable was taken from the World Bank data set. According to the life cycle hypothesis its coefficient should be negative.

(b) Urban population: proportion of total population that lives in urban areas. This variable was taken from the World Bank data set, and according to the precautionary savings model discussed above, its sign is expected to be negative.

(c) Government savings: This variable was obtained from the IMF's data set. Its coefficient is expected to be negative, capturing the fact that government savings will tend to crowd out private savings. An important issue is how close to -1.0 this coefficient is. If it is not significantly different from minus one, increases in government savings will not be fully offset by reductions in public savings.

(d) Growth: This variable was defined as a three-year moving average of the rate of growth of per capita GDP. The raw data were taken from Summers and Heston (1991). The life cycle model suggests that its coefficient should be positive. Carroll and Summers (1991), however, have argued that in a more complete model of consumer behavior, the relationship between growth and savings is ambiguous, and that in the

22. In the cross section estimates I dealt with 1983-92 averages. In this case endogenous variables for 1970-82 were used as some of the instruments. Although this procedure does not fully deal with causality, it provides a convenient way to handle the simultaneity issue. 
TABLE 2

DETERMINANTS OF PRIVATE SAVINGS

Instrumental Variables, Panel Data

t-statistics in parentheses

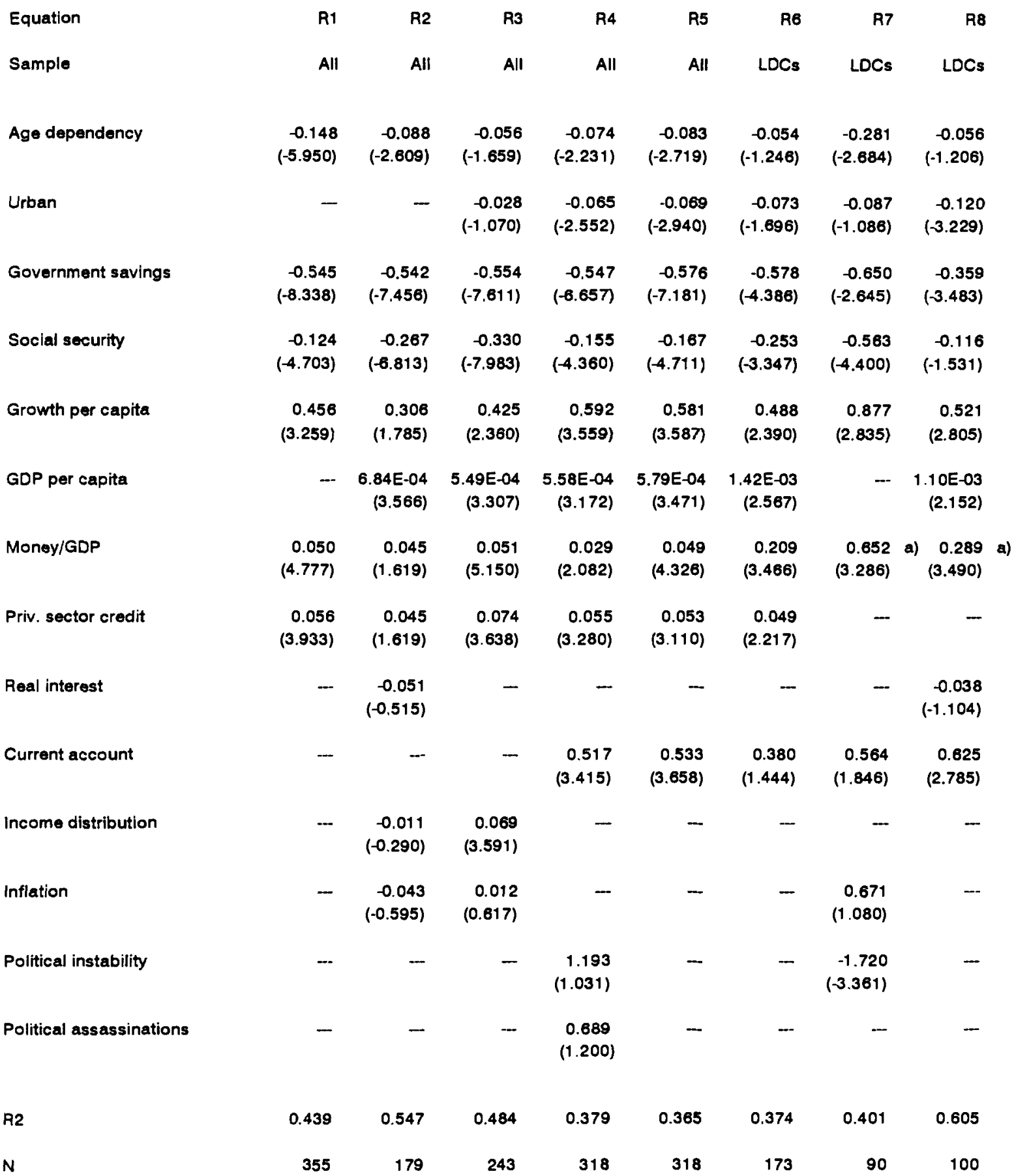

a) Beginning of period money ratio used as regressor. 
short run they should be negatively related. In order to avoid simultaneity problems the equations are estimated with instrumental variables -- see below for a detailed description on the instruments used. Carroll and Weil (1993) use causality tests and find that growth "causes" aggregate savings.

(e) GDP per capita: Taken from Summers and Heston. To the extent that more developed countries save a higher proportion of their income, its coefficient will be positive.

(f) Money/GDP: A number of variables were used. The first two were constructed as yearly ratios of M1 and M2 to GDP. Also, the ratio of the initial -- that is 1970 -- stocks of M1 and M2 to GDP were used. In all cases the raw data taken from the IMF's International Financial Statistics (IFS). This is one of the most difficult variables to interpret. If it is taken, as it traditionally been the case, as a proxy for the depth and sophistication of the financial system, its coefficient should be positive (McKinnon 1973). If, however, it is taken as measure of the extent to which different countries face a borrowing constraint, its coefficient should be negative -- see the discussion in the preceding section for details.

(g) Private credit: This variable can be considered to be a closer proxy for borrowing constraints and is defined in two alternative ways: the first is the yearly ratio of credit to the private sector to total domestic credit; the second is the same ratio for the initial year, 1970. As discussed earlier, the borrowing constraint should affect private savings positively. Both indices were constructed from raw data obtained from the IFS.

(h) Social Security: Obtained from the World Bank's data set. It is defined as the ratio of public expenditure on social security and welfare to total public expenditures. It is a proxy for expected social security benefits, and its coefficient is expected to be negative. 
(i) Real interest rate: Defined as the ex-post real deposit interest rate. The raw data were obtained from the IFS. According to the model presented above the sign of the coefficient of this variable is undetermined a priori.

(j) Current account: Defined as the ratio of the current account balance to GDP, obtained from the World Bank data set. Its coefficient measures the degree of substitutability between foreign savings (or current account deficit) and national private savings. If foreign savings crowd out private savings, the estimated coefficient of this variable would be positive.

(k) Inflation: Defined as the rate of change of the CPI. This variable captures the degree of macroeconomic stability, and its coefficient is expected to be negative.

(l) Income distribution: Defined as the ratio of income received by the poorer 40 percent over income received by the higher 10 percent. To the extent that lower income households save a smaller proportion of their income, its coefficient is expected to be positive. The data were taken from the World Bank data set.

(m) Political instability: Three variables were used. The first is a proxy for the degree of structural political instability in each country. An index defined as the frequency of transfers of government for 1971-82 was used. The other two are the frequency of politically motivated assassinations and attacks. These variables were taken from Edwards and Tabellini (1994). The expected sign of their coefficients is negative. ${ }^{23}$

23. When alternative indices -- such as the estimated probability of government change -- are used to measure political instability, the basic results reported here were maintained. 
Equations R1 through R5 in Table 2 refer to the complete sample, while equations R6-R8 are restricted to developing countries. These results are quite revealing. ${ }^{24}$ The $\mathrm{R}^{2} \mathrm{~s}$ are quite high, boarding 0.5 in most cases. As suggested by life cycle models the coefficient of the age dependency ratio is significantly negative, indicating that demographics play an important role in explaining differences in private savings across time and countries. This coincides with the results obtained by a number of authors, including Leff (1968) and Modigliani (1970) in their pioneer work. When alternative demographic variables were used instead of age dependency, the results were basically unaltered. The coefficient of the ratio of urban population is negative and significant in most regressions, supporting the "buffer stock" approach to private savings -- see Deaton (1990).

The coefficient of government savings was significantly negative in every regression. More important from a policy perspective, however, is that it was always significantly different from -1.0 . For example, in equation R1, the $95 \%$ confidence interval is $(-0.673,-0.416)$. This indicates that, although higher government savings crowd out private savings, they will not do it one-to-one, and that Ricardian equivalence does not hold strictly. The coefficient of social security is negative, and significant at conventional levels in all the regressions where it was included. This is consistent with previous findings by Feldstein (1980), and gives support to the notion that reforms that replace government run (and partially funded) social security systems, by privately-run capitalization systems will tend to result in higher private saving rates. Notice, however, that a reform of the social security system will tend to reduce government savings in the short run. The reason is that during the transition from the old regime to the new one, the government will continue to have obligations to (older) retirees, but will receive no contributions from active workers. Diamond and Valdes-

24. The countries used in the regressions were chosen according to data availability and are listed in the appendix. The rate of growth of GDP per capita, real interest rates and the current account balance were considered to be endogenous variables. The following instruments were used: constant, age dependency, lagged moving average of growth, money/GDP, private credit, lagged real interest, government savings, social security, lagged current account, income distribution, political instability, GNP per capita, government consumption ratio, lagged investment, inflation, openness, and population growth. 
Prieto (1994) have argued that Chile's privatized social security system has resulted in "excessive competition" where a very high percentage of contributions are spent in advertising.

Also, the regressions reported in Table 2 show that the rate of growth of per capita GDP is significantly positive. This result has been previously obtained by a number of authors -- most recently by Collins (1991), Bosworth (1993) and Carroll and Weil (1993) --, and provides some support to the hypothesis that there is a "virtuous circle" that goes from faster growth to increased savings to even higher growth. ${ }^{25}$ When GDP per capita was added to the regressions its coefficient was always positive and significant, indicating that with other things given more advanced counties tend to save a higher percentage of GDP -- Collins (1991) reports a similar result in her analysis of ten developing countries.

The next three independent variables in Table 2 -- money/GDP, private credit and real interest rate -- are proxies that try to capture the extent of development of the financial market, the severity of the borrowing constraint, and the degree of "financial repression". The coefficient of the money/GDP ratio is always significantly positive, suggesting that countries with a "deeper" financial system will tend to have higher private saving rates. In order to investigate the robustness of this result, several alternative definitions of this index were used, including yearly M1 and M2 ratios, as well as beginning of period ratios. When this was done, however, the estimates did not change in any significant way. The coefficient of private credit was also significantly positive in all regressions were it was included. Overall, these results do not provide support for the view that borrowing constraints have resulted in lower savings. This contradicts evidence presented by Schmidt-Hebbel et al (1992) and by Jappelli and Pagano (1994) who found, on different samples, that relaxing borrowing constraints have negatively affected private savings. There are several possible

25. The fact that the regressions reported in Table 2 have been obtained using instrumental variables supports the idea that this positive coefficient is not simply the consequence of a simultaneity bias. Carroll and Weil (1993) present Granger causality tests that suggest that growth Granger-cause aggregate savings. 
explanations for these results, including that the share of private credit is a (very) poor proxy for borrowing constraints, and that these operate on household savings only, and not on corporate or total private savings. Unfortunately, more adequates measures of borrowing (or liquidity) constraints, such as the down payment required to buy a house, are only available for a small number of advanced countries. The role of this type of constraints -- including restrictions on consumer credit -- possibly constitute one of the most important unresolved issues in research on savings behavior. In order to investigate the issue further I estimated cross section regressions using average data for 1983-92. The instrumental variables estimates yielded a positive coefficient for the money/GDP ratio, and a negative one for the ratio of private sector credit over total domestic credit, confirming the view that the role of borrowing constraint constitutes an important area for future research. The following is an illustration of the type of result obtained (numbers in parentheses are t-statistics):

$$
\begin{aligned}
& \text { PSAV }=1.83(3.2) \text { Growth }-.35(-2.1) \text { GovSav }-1.0(-1.9) \text { Old } \\
& -.619(-2.2) \text { Young }+.138(1.6) \text { Money/GDP }-.062(-1.9) \text { Private Credit } \\
& -.104(-1.7) \text { Social security }+49.233(13.474) ; \quad \mathrm{N}=38 ; \mathrm{R}^{2}=.57
\end{aligned}
$$

More detailed and convincing analyses on the role of borrowing constraints will require constructing more reliable indicators of the extent of these constraints.

The coefficients of real interest rates in Table 2 were insignificant in every where it was included. This is consistent with results obtained by a number of previous researchers (see McKinnon 1993, for example); moreover, when an interactive real interest rate-real GDP per capita term was included, the result did not support Ogaki's et al (1994) finding suggesting that the degree of intertemporal substitutability in consumption increases with the degree of development. When alternative measures of the efficiency of the financial system, such as the spread 
between lending and deposit interest rates, were included in the regressions their coefficients were not significant. ${ }^{26}$

The current account balance was significantly positive in every regression, but the estimated coefficient was smaller than one, indicating that increases in foreign savings crowd out private savings in a less than one to one fashion. Also, the inflation and political instability coefficients were not significant in any of the regressions where they were included. Income distribution data are available for a very small number of countries -- mostly advanced. In one of the regressions its coefficient was significantly positive; additional data would be required, however, to get a clearer perspective on the role of this variable.

In order to test for the robustness of the results, I performed a series of tests. In particular, I added variables related to macroeconomic stability (variability of inflation), the open economy (degree of openness and variability of the real exchange rate), and the structure of the economy (share of manufacturing, mining and agriculture in GDP). Their coefficients were not significant. I also analyzed whether the results reported in Table 2 were driven by outliers. In order to do this I estimated Cook's distance statistics to identify variables with a high degree of "influence" in the results. These observations turned out to correspond to Bolivia; when they were excluded from the regression, however, the results discussed above did not change in any relevant way. Finally, I re-estimated the equations using White's procedure for estimating the variance-covariance matrix under heteroskedasticity, again without altering the results commented above.

The computation of standardized beta coefficients indicates that growth of per capita GDP is the most important variable for explaining cross country differences in private savings. This coincides with Bosworth's (1993) results. In equation R2, for example, the beta statistic for growth is 3.43 ; the other variables with relatively high betas were government savings (-1.36) and money/GDP ratio $(0.87)$.

26. From theoretical and empirical points of view, the (possible) effects of interest rates -- and other incentives -- on private savings constitute a major controversy. 
One of the questions asked in the introduction to this paper was why are saving rates so low in Latin America? The results presented in Table 2 suggest that this can be the consequence of a series of factors. First, (some of) the coefficients of the private savings equation for Latin America may be different from those for the rest of the countries in the sample. Second, even if the same equation can describe private savings across regions, the value of the right hand side variables may be different in the Latin nations. Naturally, a third possible explanation is a combination of the previous two.

In order to test whether the coefficients pertinent for the Latin countries were different, I reestimated the equations in Table 2 with Latin America dummy variables for every coefficient -- see Table 3 for the results obtained in the case of equation R5. As can be seen, only the dummies for two of the coefficients -- urban population and GDP per capita are significantly different from zero. ${ }^{27}$ In particular, this suggests that the degree of urbanization plays a significantly more negative role in Latin America than in the rest of the sample. A possible explanation for this is that, within the context of the "buffer stock" approach to savings, the traditional role of government in providing a safety net in the cities has reduced precautionary savings. What is more important from these results, however, is that they suggest that the coefficients of the policy variables and of growth are not significantly different across samples.

Regarding the second possible explanation, an analysis of the right hand side variables unveils significant differences between the Latin American countries and the rest of the sample. This is the case both for demographic variables (Latin America has a much higher age dependency ratio, for example), growth, and policy variables such as social security and government savings -- see Table 4. Interestingly, the results in Tables 3 and 4 suggest that the poor levels of Latin American private savings are mostly a consequence of different levels of savings determinants, and not so much due

27. The F-test for the hypothesis that all coefficients (including the constant) are jointly equal to zero is equal to 3.75 , indicating that the null is rejected at the $1 \%$ level. 
TABLE 3

\section{PRIVATE SAVINGS AND LATIN AMERICA \\ Dummy Variables Estimation $\left({ }^{*}\right)$}

t-statistics in parentheses

Coefficient

LAC dummies

estimates

\begin{tabular}{|c|c|c|}
\hline Age dependency & -0.133 & -0.174 \\
\hline & $(-3.143)$ & $(-0.729)$ \\
\hline Urban & 0.013 & -0.626 \\
\hline & $(0.450)$ & $(-3.084)$ \\
\hline Government savings & -0.596 & 0.383 \\
\hline & $(-6.524)$ & $(1.195)$ \\
\hline Growth per capita & 0.649 & -0.486 \\
\hline & $(2.923)$ & $(-1.559)$ \\
\hline GDP per capita & $-5.6 \mathrm{E}-05$ & 4.0E-04 \\
\hline & $(-0.262)$ & (3.298) \\
\hline Money/GDP & 0.041 & 0.055 \\
\hline & $(3.826)$ & $(0.206)$ \\
\hline Priv. sector credit & 0.062 & -0.098 \\
\hline & (3.298) & $(-1.466)$ \\
\hline Social security & -0.119 & 0.013 \\
\hline & $(-2.976)$ & $(0.990)$ \\
\hline Current account & 0.527 & -0.384 \\
\hline & $(3.357)$ & $(-1.289)$ \\
\hline R2 & 0.454 & $\cdots$ \\
\hline $\mathbf{N}$ & 306 & $\cdots$ \\
\hline$F$ & $\cdots$ & 3.75 \\
\hline
\end{tabular}

(*) This equation was estimated Including Latin America dummy variables for each regressor. The coefficients on the rightmost column represent the dummy estimates. 
TABLE 4

\section{LATIN AMERICA AND REST OF THE SAMPLE GENERAL STATISTICS}

Private savings

Government savings

Growth

M1/GDP

M2/GDP

Private credit

Current account

Age dependency

Social security

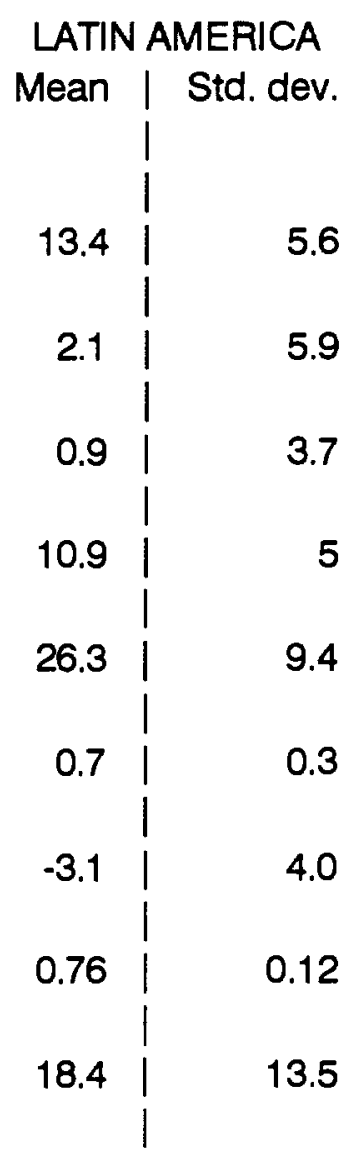

\begin{tabular}{|c|c|}
\hline \multicolumn{2}{|c|}{ REST OF THE SAMP } \\
\hline Mean & Std. dev. \\
\hline 18.9 & 7.6 \\
\hline 2.5 & 14.9 \\
\hline 1.1 & 0.3 \\
\hline 22.3 & 28.7 \\
\hline 53.7 & 23.9 \\
\hline 0.67 & 0.31 \\
\hline-2.8 & 4.2 \\
\hline 0.67 & 0.19 \\
\hline 16.8 & 16.0 \\
\hline
\end{tabular}


to structural differences in the private savings function. In that regard, the expected decline in Latin America's dependency ratio (a result of the region's demographic transition) is likely to result in an increase in private saving rations.

\section{IV.2 Government Savings}

Table 5 contains the results obtained from instrumental variable estimations of government savings equations using both panel data as well as cross country variables for 1983-92. ${ }^{28}$ In addition to political instability, and political polarization -- proxied by politically motivated attacks and assassinations -- some of the independent variables included in the private savings regressions were incorporated into the analysis. ${ }^{29}$ The dependent variable was obtained from the IMF, and the independent variables were defined as discussed above.

The results obtained differ from those for private savings, reported in Table 2, and provide some support for the political economy perspective to government savings. In every equation the coefficient of political instability was significantly negative. This suggests that in countries with more unstable political environments, public savings will tend to be lower than in countries with a more stable political environment. Interestingly enough, when alternative measures of political instability were used -such as the estimated probability of government changes --, the results were maintained. However, the proxies for polarization -- politically motivated attacks and assassinations -- were significantly different from zero in only some of the regressions. It is important to note, however, that in spite of these positive results, the regressions reported here do not allow discrimination between the political-economy strategic behavior approach proposed in section III of this paper, and alternative models based

28. The following instruments were used: a constant, lagged growth, political instability, assassinations, attacks, social security, lagged current account balance in 1970-82, age dependency, share of government consumption, GNP per capita, money/GDP ratio, inflation lagged investment, openness, and social security.

29. See Edward and Tabellini (1994) for a discussion on the sources for these variables. 
TABLE 5

\section{DETERMINANTS OF GOVERNMENT SAVINGS}

t-statistics in parentheses

\begin{tabular}{|c|c|c|c|}
\hline Equation & $\mathrm{Rg}$ & R10 & R11 \\
\hline Sample & Panel (a) & Panel & Cross-section \\
\hline Estimation method & IV & IV - Fixed effects & IV \\
\hline \multirow[t]{2}{*}{ Age dependency } & 1.657 & 0.402 & 0.042 \\
\hline & $(0.298)$ & $(0.321)$ & $(0.533)$ \\
\hline \multirow[t]{2}{*}{ Urban } & 0.078 & -0.153 & $\cdots$ \\
\hline & $(3.334)$ & $(-0.941)$ & \\
\hline \multirow[t]{2}{*}{ Social security } & $\cdots$ & - & -0.008 \\
\hline & & & $(-0.103)$ \\
\hline \multirow[t]{2}{*}{ Growth per capita } & 0.632 & 0.794 & 1.801 \\
\hline & $(4.140)$ & $(7.270)$ & $(3.285)$ \\
\hline \multirow[t]{2}{*}{ GDP per capita } & $-4.0 \mathrm{E}-04$ & $-6.2 E-04$ & $-1.8 E-04$ \\
\hline & $(-2.627)$ & $(-2.412)$ & $(-1.032)$ \\
\hline \multirow[t]{2}{*}{ Money/GDP } & -0.012 & -0.001 & -0.074 \\
\hline & $(-1.240)$ & $(-0.183)$ & $(-0.747)$ \\
\hline \multirow[t]{2}{*}{ Current account } & 0.378 & 0.532 & 0.822 \\
\hline & $(5.044)$ & $(4.570)$ & $(2.449)$ \\
\hline \multirow[t]{2}{*}{ Political instability } & -0.820 & -0.363 & -0.511 \\
\hline & $(-2.900)$ & $(-5.183)$ & $(-2.569)$ \\
\hline \multirow[t]{2}{*}{ Political assassinations } & -0.181 & -- & $\cdots$ \\
\hline & $(-0.259)$ & & \\
\hline \multirow[t]{2}{*}{ Attacks } & -0.0901 & -0.018 & -0.002 \\
\hline & $(-2.701)$ & $(-4.149)$ & $(-0.358)$ \\
\hline $\mathrm{R} 2$ & 0.439 & 0.484 & 0.365 \\
\hline $\mathbf{N}$ & 334 & 334 & 38 \\
\hline
\end{tabular}

a) The following instruments were used: assassinations, lagged growth per capita, lagged investment, ratio of social security expenditures to total expenditure, frequency of transfer of political power, attacks, lagged current account balance, urbanization, opennness, inflation, ratio of broad money to GDP, government consumption. 
on governments political weakness -- see Edwards and Tabellini (1994) for a discussion on these two families of models.

As in the case of private savings, the coefficient of growth is significantly positive. Moreover, the computation of standardized beta coefficients indicates that this is the most important variable in explaining cross country differences in government savings (political instability is the second most important beta coefficient).

Interestingly enough, and contrary to the private savings case reported in Table 2 , neither the demographics, social security, or money/GDP variables have significant coefficients. As in the case of private savings, the coefficient of the current account is significantly positive, indicating that a higher level of foreign savings -- that is a reduction in the current account balance -- has been associated with a lower government savings rate. Its coefficient, however, is significantly below unity in both panel regressions reported here -- for example, in equation R10 the $95 \%$ confidence interval is $(0.29,0.75)$, indicating that the degree of offset is not one to one.

\section{Concluding Remarks}

Most empirical studies on national savings have either aggregated private and government savings, or have concentrated on private savings behavior under the assumption that government savings are exogenous. This is indeed puzzling. There are not only solid theoretical reasons for believing that both types of savings are determined in very different ways, but, what is perhaps more important, in rapidly growing economies government savings have made fundamental contributions to national savings. This paper provides evidence that clearly suggests that the processes of determination of private and government savings are significantly different. While private savings respond to demographic variables, social security expenditures, and the depth of the financial sector, government savings do not. Government savings, on the other hand, are affected by an important type of variable that does not impact on private savings: the degree of political instability of the country in question.

However, both private and government savings are affected by real growth and by the current account balance or foreign savings. 
From a policy perspective, the results reported in this paper suggest that there are a number of possible avenues -- many of them discussed in policy literature -- for raising private savings. An increase in the degree of depth of the financial sector will tend to have an important effect. It is interesting to notice that for the case of Latin America the ratio of M1 to GDP was almost one half of what it was in the rest of the sample. What is less clear, however, are the mechanisms through which this could happen. Also, the results presented here have not resolved the question of the impact of borrowing constraints. While the panel data analysis did not unearth such an effect, cross section results do provide some evidence in support of the notion that relaxing the borrowing constraint may reduce savings. Further research on this issue will be needed before a clearer picture emerges. At this point, however, it seems that the most fruitful type of research along these lines would be microeconomic in nature. In particular, investigating how the increased access to consumption credit affects household saving decisions would be particularly important.

The results reported in this paper also suggest that the reduction of governmentprovided social security benefits increase private savings. Again, however, additional progress in this area would require detailed microeconomic analysis of specific country experiences. In that sense, the study of the Chilean case appears to be particularly important. Specifically, it is important to investigate at least three issues regarding this case: first, whether, as pointed out above, this experience has resulted in excessively high administration costs; second, what were the actual effects of this reform on total aggregate savings during the transition; and third, what has been the actual microeconomic evidence regarding the effects of the reforms on private savings.

Perhaps one of the most important results refers to the role of public savings as determinants of private savings. While the results strongly suggest that higher government savings depress private savings, they do it in less than a one to one fashion. In fact, the results suggest that an increase in government savings of 1 percent generate a decline in private savings of approximately 0.55 percent, with the consequent increase in national aggregate savings of 0.45 percent. To the extent that 
this net increase in national savings result in higher capital accumulation and growth, it is possible to get started on the "virtuous circle" discussed above.

It should be noted, however, that due to the nature of the data -- short time series and rather large number of cross sections --, the results reported in this paper do not provide enough information regarding the transition from low to higher saving rates. However, evidence from a score of countries - including the "East Asian miracle" nations - suggests that the increase in private domestic savings ratios is a rather slow process (World Bank 1993b). This evidence also indicates that a drastic increase of private savings has usually been affected by an important factor not captured in the regression analysis: the creation of an institutional environment that instills confidence on small savers-the case of postal savings in East Asia is a good example of this type of institution.

Another important finding is that government savings, in turn, is positively affected by the creation of social and political institutions that reduce the degree of political instability. Countries that have a "national project" and where political forces coexist in relative harmony seem to find it easier to increase government savings. This suggests, then, that a strengthening of democracy has important, and fairly direct, positive effects over growth and economic progress.

As a consequence of the debt crisis most Latin American countries had to reform their public finances. Tax systems have been rationalized and become more efficient; the number of tax rates was reduced, their level was harmonized with international rates, and the number of exemptions eliminated. Tables 6 and 7 provide a summary of the most important reforms in tax rates. In spite of these important changes, however, in some countries public sector revenues continue to be rather low -- see Edwards (1993). In fact, the increases in government savings reported in Table 1 have largely attained through a reduction in expenditures -- especially in infrastructure -- and not through higher tax revenues. 
TABLE 6 - TAX RATES IN THE PRE-REFORM AND POST REFORM PERIODS (percent)

\begin{tabular}{|c|c|c|c|c|c|c|}
\hline \multirow[t]{2}{*}{ Country } & \multicolumn{2}{|c|}{ Personal Income Tax } & \multicolumn{2}{|c|}{$\begin{array}{l}\text { Corporate Income } \\
\text { Tax }\end{array}$} & \multicolumn{2}{|c|}{$\begin{array}{l}\text { Withholding Taxes } \\
\text { on Foreign } \\
\text { Remittances } \underline{1 /}\end{array}$} \\
\hline & $1985-86$ & 1991 & 1986 & 1992 & 1986 & 1993 \\
\hline Argentina & $16.5-4.5$ & $6-30$ & $0-33$ & 20 & 23 & 17 \\
\hline Bolivia & $\ldots-30$ & 13 & $0-30$ & 0 & 25 & 13 \\
\hline Brazil & $0-60$ & $10-25$ & $29-50$ & $25-40$ & 25 & 22 \\
\hline Chile & $0-57$ & $5-50$ & $10-37$ & $15-35$ & 40 & 38 \\
\hline Colombia & $\ldots-49$ & $5-30$ & 40 & 30 & 40 & 12 \\
\hline Costa Rica & $5-50$ & $10-25$ & $0-50$ & 30 & 15 & 18 \\
\hline $\begin{array}{l}\text { Dominican } \\
\text { Republic }\end{array}$ & $2-73$ & $3-70$ & $0-49.3$ & $0-49.3$ & 20 & 30 \\
\hline Ecuador & $19-40$ & $10-25$ & $0-59$ & $0-44.4$ & 40 & 36 \\
\hline El Salvador & $3-60$ & $10-50$ & $0-30$ & $0-25$ & 22 & 20 \\
\hline Guatemala & $11-48$ & $4-34$ & $0-42$ & $12-34$ & 16 & 17 \\
\hline Honduras & $3-40$ & $3-40$ & $0-55$ & $0-40.2$ & 10 & 18 \\
\hline Mexico & $3-55$ & $3-55$ & $5-42$ & $0-35$ & 37 & 22 \\
\hline Nicaragua & $15-50$ & $6-50$ & $0-45$ & $0-35.5$ & 20 & 30 \\
\hline Panama & $13-56$ & $2.5-56$ & $0-50$ & $2.5-45$ & 30 & 22 \\
\hline Paraguay & $5-30$ & 0 & $0-30$ & $0-30$ & 23 & 25 \\
\hline Peru & $2-56$ & $5-56$ & $0-40$ & $0-30$ & 42 & 19 \\
\hline Uruguay & 0 & 0 & $0-30$ & $0-30$ & 30 & - \\
\hline Venezuela & $12-45$ & $4.5-45$ & $18-67.7$ & $20-67.7$ & 20 & 15 \\
\hline Regional average & $5-36$ & $7-47$ & $3.4-46.3$ & $8.6-36.5$ & 27 & 22 \\
\hline
\end{tabular}

$\underline{1}$ Simple average.

Source: Shome (1994). 
TABLE 7 - VALUE-ADDED TAX (Percentage Rates)

\begin{tabular}{lccc}
\hline Country & $\begin{array}{c}\text { Date VAT } \\
\text { Introduced } \\
\text { or Proposed }\end{array}$ & At Introduction & January 1994 \\
\hline Bolivia & Oct. 1973 & $5,10,15$ & $14.92 \underline{2} /$ \\
Brazil 3/ & Jan. 1967 & 15 & 9,11 \\
Brazil 4/ & Jan. 1967 & 15 & 17 \\
Chile & Mar. 1975 & 8,20 & 18 \\
Colombia & Jan. 1975 & $4,6,10$ & $8,14,20,35,45$ \\
Costa Rica & Jan. 1975 & 10 & 8 \\
Dominican Republic & Jan. 1983 & 6 & 6 \\
Ecuador & Jul. 1970 & 4,10 & 10 \\
El Salvador & Sep. 1992 & 10 & 10 \\
Guatemala & Aug. 1983 & 7 & 7 \\
Haiti & Nov. 1982 & 7 & 10 \\
Honduras & Jan. 1976 & 3 & 7,10 \\
Jamaica & Oct. 1991 & 10 & 12.5 \\
Mexico & Jan. 1980 & 10 & 10 \\
Nicaragua & Jan. 1975 & 6 & $5,6,10$ \\
Panama & Mar. 1977 & 5 & 5,10 \\
Paraguay & Jul. 1993 & 12 & 10 \\
Peru & Jul. 1976 & 20,40 & 10 \\
Venezuela & Oct. 1993 & 10 & \\
\hline & & 5 & 10 \\
\hline
\end{tabular}

1/ Suplementary VAT rates of 8 and 9 percent on non-capital goods imports: through "catch-up", these can revert to 18 percent retail.

2/ Effective rate (legislated tax-inclusive rate is 13 percent).

$\underline{3} /$ On interstate transactions depending on region.

4/ On interstate transactions.

Source: Shome (1994). 
APPENDIX: Countries Included in the Panel Empirical Analysis

\begin{tabular}{cl} 
IMF code & Country \\
122 & Austria \\
124 & Belgium \\
128 & Denmark \\
134 & Germany \\
136 & Italy \\
142 & Norway \\
156 & Canada \\
172 & Finland \\
178 & Ireland \\
182 & Portugal \\
186 & Turkey \\
196 & New Zealand \\
218 & Bolivia \\
223 & Brazil \\
228 & Chile \\
233 & Colombia \\
253 & El Salvador \\
273 & Mexico \\
288 & Paraguay \\
299 & Venezuela \\
429 & Iran \\
524 & Sri Lanka \\
548 & Malaysia \\
564 & Pakistan \\
566 & Philippines \\
576 & Singapore \\
578 & Thailand \\
622 & Cameroon \\
652 & Ghana \\
664 & Kenya \\
684 & Mauritius \\
686 & Morocco \\
694 & Nigeria \\
724 & Sierra Leone \\
742 & Togo \\
744 & Tunisia \\
& \\
\hline &
\end{tabular}




\section{References}

Aghevli, B., J. Boughton, P. Montiel, D. Villanueva and G. Woglom (1990); The Role of National Saving in the World Economy, IMF Occasional Paper No. 67, Washington, D.C., March.

Barro, R. (1974); "Are Government Bonds Net Wealth?", Journal of Political Economy, Vol. 82.

Barro, R. (1991); "Economic Growth in a Cross-Section of Countries", Quarterly Journal of Economics, Vol. 106, August.

Bosworth, B. (1993); Savings and Investment in the Open Economy, Washington, D.C., The Brookings Institution.

Boskin, M. (1978); "Taxation, Savings and the Rate of Interest", Journal of Political Economy, Vol. 86, Supplement.

Caballero, R. (1990); "Consumption Puzzles and Precautionary savings", Journal of Monetary Economics, Vol. 25.

Carroll, C. and L. Summers (1991); "Consumption Growth Parallels Income Growth", in D. Bernheim and J. Shoven (eds.), National Saving and Economic Performance, Chicago, NBER / University of Chicago Press.

Carroll, C. an D. Weil (1993); "Savings and Growth: A Reinterpretation", NBER Working Paper No. 4470, September.

Collins, S. (1991), "Saving Behavior in Ten Developing Countries", in D. Bernheim and J. Shoven (eds.), National Saving and Economic Performance, Chicago, NBER / University of Chicago Press.

Corbo, V. and K. Schmidt-Hebbel (1991); "Public Policies and Saving in Developing Countries", Journal of Development Economics, Vol. 36, No. 1.

Cukierman, A., S. Edwards and G. Tabellini (1992); "Seigniorage, Political Instability and Inflation", American Economic Review, Vol. 72, June.

Deaton, A. (1990) "Savings in Developing Countries: Theory and Review", World Bank Economic Review.

Deaton, A. (1995), "Growth and Savings: What do we Know and What Might we Learn", Working Paper, Princeton University. 
De Long, B. and L. Summers (1991); "Equipment Investment and Economic Growth", Quarterly Journal of Economics, Vol. 106, August.

Diamond, P. and S. Valdés-Prieto (1994); "Social Security Reforms", in B. Bosworth, R. Dornbusch and R. Labán (eds.); The Chilean Economy: Policy Lessons and Challenges, Washington, D.C., Brookings.

Dornbusch, R. (1991); "Policies to Move From Stabilization to Growth", Proceedings of the World Bank Annual Conference on Development Economics, Washington, D.C., The World Bank.

Dornbusch, R. and S. Edwards (eds.) (1994); Stabilization, Economic Reform and Growth, Chicago, University of Chicago Press, forthcoming.

Doshi, K. (1994); "Determinants of the Saving Rate: An International Comparison", Contemporary Economic Policy, Vol. 12, January, 37-47.

Edwards, S. (1988); "Financial Deregulation and Segmented Capital Markets: The Case of Korea", World Development, Vol. 16, January.

Edwards, S. (1989); Real Exchange Rates, Devaluation, and Adjustment: Exchange Rate Policy in Developing Countries, Cambridge, Mass., MIT Press.

Edwards, S. (1992); "Trade Orientations, Distortions and Growth in Developing Countries", Journal of Development Economics, Vol. 39, No. 1.

Edwards, S. (1993); Latin America and the Caribbean a Decade After the Debt Crisis, Latin America and the Caribbean Region, The World Bank, Washington, D.C.

Edwards, S. and A. Cox-Edwards (1991); Monetarism and Liberalization: The Chilean Experiment, Chicago, University of Chicago Press.

Edwards, S. and G. Tabellini (1994); "Political Instability, Political Weakness and Inflation: An Empirical Analysis" in C. Sims (ed.) Advances in Econometrics, Cambridge, Cambridge University Press.

Feldstein, M. (1980); "International Differences in Social Security and Saving", Journal of Public Economics, Vol. 12.

Feldstein, M. (1994a), "Tax Policy and International Capital Flows", NBER Working Paper No. 4851.

Feldstein, M. (1994b), "Fiscal Policies, Capital Formation, and Capitalism", NBER Working Paper No. 4885 
Feldstein, M. and P. Bacchetta (1991); "National Saving and International Investment", in D. Bernheim and J. Shoven (eds.), National Saving and Economic Performance, Chicago, NBER / University of Chicago Press.

Feldstein, M. and C. Horioka (1980); "Domestic Saving and International Capital Flows", Economic Journal, Vol. 90, June.

Frankel, J. (1985); "International Capital Mobility and Crowding Out in the U.S. Economy", NBER Working Paper No. 1773, December.

Fry, M. (1988); Money, Interest and Banking in Economic Development, Baltimore, Johns Hopkins University Press.

Gelb, A. (1989); "Financial Policies, Growth and Efficiency", Policy Research Working Paper 202, The World Bank, Washington, D.C.

Gersovitz, M. (1988); "Savings and Development", in Chenery, H. and Srinivasan, T. (eds.); Handbook of Development Economics Vol. 1, Amsterdam, North- Holland.

Giovannini, A. (1983); "The Interest Elasticity of Savings in Developing Countries: The Existing Evidence", World Development, Vol. 11, July.

Grossman, G. and E. Helpman (1991); Innovation and Growth in the Global Economy, Cambridge, Mass., MIT Press.

Gylfason, T. (1993); "Optimal Saving, Interest Rates and Endogenous Growth", Seminar Paper No. 539, University of Stockholm, September.

Hayashi, F. (1986); "Why is Japan's Saving Rate so Apparently High?", in NBER Macroeconomics Annual 1986, Cambridge, MIT Press.

Hayashi, F. (1987); "Tests for Liquidity Constraints: A Critical Survey and Some New Observations", in T. Bewley (ed.), Advances in Econometrics, New York, Cambridge University Press.

Jappelli, T. and M. Pagano (1994); "Saving, Growth, and Liquidity Constraints", Quarterly Journal of Economics, Vol. 109, February.

King, R. and R. Levine (1993); "Finance, Entrepreneurship, and Growth", Paper presented World Bank Conference: "How Do National Policies Affect Long-Term Growth?" Washington, D.C., February. 
King, R. and R. Levine (1994); "Capital Fundamentalism, Economic Development and Economic Growth", Policy Research Working Paper No. 1285, The World Bank, Washington, D.C.

Kotlikoff, L. (1984); "Taxation and Savings: A Neoclassical Perspective", Journal of Economic Literature, Vol. 22, December 1984.

Leff, N. (1968); Economic Policy-making and Development in Brazil, 1947-1964, New York, Wiley.

Lewis, A. (1955); The Theory of Economic Growth, London, Allen and Unwin.

Lucas, R. (1988); "On the Mechanics of Economic Development", Journal of Monetary Economics, Vol. 22, July.

McKinnon, R. (1973); Money and Capital in Economic Development, Washington, D.C., Brookings Institution.

McKinnon, R. (1991); The Order of Economic Liberalization: Financial Control in the Transition to a Market Economy, Baltimore, Johns Hopkins University Press.

Modigliani (1970);

Modigliani, F. (1980); "The Life Cycle Hypothesis of Savings Twenty Years Later", in M. Parkin (ed.), Contemporary Issues in Economics, Manchester, Manchester University Press.

Modigliani, F. and R. Brumberg (1954); "Utility Analysis and the Consumption Function: An Interpretation of Cross-Section Data", in K. Kurihara (ed.), PostKeynesian Economics, New Jersey, Rutgers University Press.

Montiel, P. (1994); "Capital Mobility in Developing Countries", World Bank Economic Review, Vol. 8, September.

Obstfeld, M. (1995) "Effects of Foreign Resource Inflows on Savings: a Methodological Overview", University of California, Berkeley.

Ogaki, M., J. Ostry and C. Reinhart (1994); "Saving Behavior in Low- and MiddleIncome Developing Countries: A Comparison" Working Paper, International Monetary Fund, Research Department.

Persson, T. and G. Tabellini (1990); Macroeconomic Policy, Credibility and Politics, New York, Harwood Academic. 
Rebelo, S. (1991); "Long Run Policy Analysis and Long Run Growth", Journal of Political Economy, Vol. 99, June.

Romer, P. (1986); "Increasing Returns and Long-Run Growth", Journal of Political Economy, Vol. 94.

Sala-i-Martin, X. (1992); "Public Welfare and Growth", Working Paper, Economic Growth Center, Yale University, June.

Schmidt-Hebbel, K., L. Serven, and A. Solimano (1994); "Savings and Investment: Paradigms, Puzzles, Policies", mimeo, Policy Research Department, World Bank, October.

Schmidt-Hebbel, K., S. Webb and G. Corsetti (1992); "Household Savings in Developing Countries", World Bank Economic Review, Vol. 6, September.

Shaw, E. (1973); Financial Deepening in Economic Development, New York, Oxford University Press.

Solow, R. (1956); "A Contribution to the Theory of Economic Growth", Quarterly Journal of Economics, Vol. 70, February.

Summers, R. and A. Heston (1991); "The Penn World Table (Mark 5): An Expanded Set of International Comparisons 1950-1988", Quarterly Journal of Economics, Vol. 106, August.

World Bank (1993a); World Development Report, New York, Oxford University Press.

World Bank (1993b); The East Asian Miracle: Economic Growth and Public Policy, New York, Oxford University Press.

Young, A. (1994); "The Tyranny of Numbers: Confronting the Statistical Evidence of the East Asian Growth Experience", NBER Working Paper No. 4680, March.

Zeldes, S. (1989); "Consumption and Liquidity Constraints: An Empirical Investigation", Journal of Political Economy, Vol. 97, April. 